\title{
A Pilot Study of an Online Intelligent Environmental Observation System for Monitoring and Evaluating Public Health Hazard from Indoor and Outdoor Pollutants
}

\author{
Vasilis Kanellopoulos, Andreas Andrikopoulos, Constantinos Koutsojannis* \\ Health Physics \& Computational Intelligence Lab, University of Patras, Patras, Greece \\ Email address: \\ ckoutsog@upatras.gr (C. Koutsojannis) \\ ${ }^{*}$ Corresponding author \\ To cite this article: \\ Vasilis Kanellopoulos, Andreas Andrikopoulos, Constantinos Koutsojannis. A Pilot Study of an Online Intelligent Environmental \\ Observation System for Monitoring and Evaluating Public Health Hazard from Indoor and Outdoor Pollutants. American Journal of \\ Environmental Protection. Vol. 8, No. 6, 2019, pp. 133-164. doi: 10.11648/j.ajep.20190806.14
}

Received: April 10, 2019; Accepted: December 6, 2019; Published: December 24, 2019

\begin{abstract}
The overall aim of this research is the prevention of environmental risk and impact, through the establishment of a present-day environmental observatory centre, equipped with an intelligent monitoring, management and evaluating system. Detecting the environmental pollutants in a timely manner (forecasting), potentially related to adverse health effects while their frequency appears to have increased, shall contribute crucially to avoiding or reducing further inhabitants' exposure to pollutants in high environmental charging areas. A plurality of data will be collected and analyzed in the pilot Observatory. All these data will be gathered by measuring various environmental parameters (physicochemical, microbiological, ionized and not ionized radiation, dust, noise), a number of which will be transmitted wireless from small scale monitoring stations. The data base (territorial distribution of samples, number and frequency of sampling, analyze results, toxicity and risk indicators of environmental pollutants), will be enriched daily/weekly, with satellite data, meteorological data and satellite photographs (image analysis). With the collection, processing and analysis of measured values for various kinds of pollutants from environmental overloaded surfaces, useful conclusions are drawn regarding to the "pollution tendency" in every different area and the possible effects on human in combination with geography and geomorphology. With the use of artificial intelligence (AI) in human body simulators (whole body phantom models) we intend to make a more accurate qualitative and quantitative forecast: worst-best scenario, about as the life quality for residents -who may be exposed to the pollutants- as the direct or indirect medium to long-term adverse effects.
\end{abstract}

Keywords: Intelligent, Environmental, Observation, Health Hazard, Pollution

\section{Introduction}

As environmental pollution, is considered any natural quality deterioration of planet's natural elements as effect of human activities. The environmental threats at the health concern the pathogenic effects biological, chemical and natural factors. The environmental pollutants constitute a "chemical load" which human body cannot unload and does not the mechanisms in order to it can him degradation and him remove. The problem is the extremely difficult control of the pollutants. Many studies, associated with the environmental pollution and its negative impact on human health, have been conducted. These researches are related to water bodies or water sources, air, soil, ionizing or nonionizing radiation and health effects or risks of human exposure to pollutants. More specifically the overall methodology is categorized to:

\subsection{Related Work for Air Pollution}

The majority of the methods, referred in this study, investigate how the various airborne particulate matter (PM10, PM2.5, PM1) influence human health [1, 2, 5-7, 12 $15,18,20,22-24,27,29,30,32,36]$. Other methods show the contribution of air pollutant emissions caused by airport operations or deal with the impact of dust from quarrying on human health and well-being [10-11, 25, 32, 33]. There are 
also methodologies for studying the health effects of African dust $[6,26]$. Others investigate the particulate emissions during industrial fires [8]. Priority in our study are observing and monitoring air pollution based on innovative and state of the art monitoring and modelling methodologies [16, 17]. Finally, as is presented in Table 1, development of appropriate integrated methodologies and software tools which aim to ensure the systematic and standardized assessment of the consequences of human health impact of exposure to chemicals and other physical and biological factors [2, 12-14, 19, 20, 22-26, 28-33, 35, 36].

Table 1. Literature review of methods related to air pollution.

\begin{tabular}{|c|c|c|c|c|}
\hline $\mathbf{a} / \mathbf{a}$ & Authors & Year & Title & Methodology \& Results \\
\hline 1 & $\begin{array}{l}\text { Blades, E., Naidu, R. } \\
\text { P., \& Mathison, G. E. }\end{array}$ & 1998 & $\begin{array}{l}\text { The microbiological analysis of } \\
\text { Sahara dust and its association with } \\
\text { asthma in Barbados. West Indian } \\
\text { Med. J., } 47 \text { (suppl. 2), 34-5. }\end{array}$ & $\begin{array}{l}\text { In this work investigation about the monthly variation of the } \\
\text { concentration of Sahara dust in the atmosphere through the } \\
\text { presence of micro-organisms in it. Important notice of the } \\
\text { development of asthma than the concentration of the dust. }\end{array}$ \\
\hline 2 & $\begin{array}{l}\text { Eleftheria } \\
\text { Chalvatzaki, } \\
\text { Thodoros Glytsos \& } \\
\text { Mihalis Lazaridis }\end{array}$ & 2015 & $\begin{array}{l}\text { A methodology for the determination } \\
\text { of fugitive dust emissions from landfill } \\
\text { sites, International Journal of } \\
\text { Environmental Health Research } 2015 \text {, } \\
\text { Vol. 25, No. 5, 551-569 }\end{array}$ & $\begin{array}{l}\text { A new methodology for the determination of the contribution of } \\
\text { fugitive dust emissions from landfill sites to ambient PM10 } \\
\text { concentrations and the subsequent exposure to working personnel, } \\
\text { that revealed that exposure to PM10, originating from fugitive dust } \\
\text { emissions in the landfill site, was exceeding the health protection } \\
\text { standards. The influence of the background concentration is } \\
\text { estimated close to } 23 \% \text {. }\end{array}$ \\
\hline 3 & $\begin{array}{l}\text { Ashok Kumar, } \\
\text { Naveen K. Bellam, } \\
\text { Anupma Sud }\end{array}$ & 2004 & $\begin{array}{l}\text { Performance of an industrial source } \\
\text { complex model: Predicting long - } \\
\text { term concentrations in an urban area, } \\
\text { Environmental Progress2004, Vol. } 18 . \\
\text { Issue 2, pp. 93-100 }\end{array}$ & $\begin{array}{l}\text { In this work the ISCST3 and ISCLT } 3 \text { models were used to predict } \\
\text { monthly and quarterly averages of sulfur dioxide concentrations } \\
\text { are evaluated for estimating long - term concentrations using } \\
\text { sulfur dioxide data from emission inventory of Lucas County, } \\
\text { Ohio for the year } 1990 \text {. The study suggests that the ISCST3 model } \\
\text { is better for estimating long - term concentrations of sulfur dioxide } \\
\text { as compared to the ISCLT3 model. }\end{array}$ \\
\hline 4 & $\begin{array}{l}\text { Victoria } \\
\text { Aleksandropoulou \& } \\
\text { Mihalis Lazaridis }\end{array}$ & 2013 & $\begin{array}{l}\text { Development and application of a } \\
\text { model (ExDoM) for calculating the } \\
\text { respiratory tract dose and retention of } \\
\text { particles under variable exposure } \\
\text { conditions. Air Qual Atmos Health } \\
\text { (2013) 6: } 13-26 \text {. }\end{array}$ & $\begin{array}{l}\text { The ExDoM is the model that incorporates an exposure module } \\
\text { which allows the user to set variable or static exposure conditions } \\
\text { (exposure concentration, physical exertion levels, and different } \\
\text { environments) or in the case of the physical exertion levels and } \\
\text { exposure environment to choose from a list of typical exposure } \\
\text { scenarios (activity pattern, exposure environment, and physical } \\
\text { exertion level). After the use of ExDOM, results showed that the } \\
\text { dose was enhanced for the carbonaceous fine fraction of particles } \\
\text { in the alveolar region of the lung whereas the dose of crustal } \\
\text { material dominated in the extrathoracic region. }\end{array}$ \\
\hline 5 & $\begin{array}{l}\text { Simon D. Griffiths et } \\
\text { al. }\end{array}$ & 2018 & $\begin{array}{l}\text { A study of particulate emissions } \\
\text { during } 23 \text { major industrial fires: } \\
\text { Implications for human health, } \\
\text { Environment International } 2018, \text { Vol. } \\
\text { 112, pp. } 310-323 \text {. }\end{array}$ & $\begin{array}{l}\text { In this context, 'indicative' is applied to monitoring equipment that } \\
\text { provides confirmation of the presence of particulates and indicates } \\
\text { a measured mass concentration value. In conclusion AQinMI is a } \\
\text { positive development, there is a need to consider further the } \\
\text { accuracy of the data provided and for the successful development } \\
\text { of a very short-term guideline values (i.e. minutes to hours) that } \\
\text { responders can use to determine the appropriate public health } \\
\text { response }\end{array}$ \\
\hline 6 & K. Gyan et al. & 2005 & $\begin{array}{l}\text { African dust clouds are associated } \\
\text { with increased paediatric asthma } \\
\text { accident and emergency admissions } \\
\text { on the Caribbean island of Trinidad, } \\
\text { Int J Biometeorol (2005) 49: pp. } 371- \\
376\end{array}$ & $\begin{array}{l}\text { In this work a Poisson regression model was used to determine the } \\
\text { statistical relationship between acute paediatric asthma A\&E visits } \\
\text { and Saharan dust cover with and without other variables such as } \\
\text { climatic parameters and month. The best fitting model estimated } \\
\text { that in one month, such as June, a deterioration of visibility due to } \\
\text { increased Saharan dust cover from no dust (visibility }=16 \mathrm{~km} \text { ) to } \\
\text { very dusty (visibility }=7 \mathrm{~km} \text { ) would increase a daily admission rate } \\
\text { of } 7.8 \text { patients to } 9.25 \text { when climate variables such as barometric } \\
\text { pressure and humidity were kept constant }\end{array}$ \\
\hline 7 & $\begin{array}{l}\text { Chiang C, Lai C, } \\
\text { Chou P, Li Y, and Tu } \\
\text { Y. }\end{array}$ & 1999 & $\begin{array}{l}\text { ASIA - PACIFIC Conference on the } \\
\text { Built Environment. The Study On The } \\
\text { Comprehensive Indicators Of Indoor } \\
\text { Environment Assessment For } \\
\text { Occupants' Health. (Taipei, Taiwan) } \\
\text { pp 1-7 }\end{array}$ & $\begin{array}{l}\text { This study describes the methodology of the indoor environment } \\
\text { assessment on existing buildings and intends to draft indoor- } \\
\text { environment preservation indicators, including acoustics, } \\
\text { vibration, illumination, thermal comfort, indoor air quality and } \\
\text { electromagnetic environment. It's necessary to take various aspects } \\
\text { of the environmental factors into consideration, when dealing with } \\
\text { the influence of built-environment on tenants }\end{array}$ \\
\hline 8 & $\begin{array}{l}\text { W H W Ibrahim1, E } \\
\text { Marinie, J Yunus, N } \\
\text { Asra and K Mohd } \\
\text { Sukor, }\end{array}$ & 2018 & $\begin{array}{l}\text { Air quality assessment on human well- } \\
\text { being in the vicinity of quarry site, } \\
\text { IOP Conf. Series: Earth and } \\
\text { Environmental Science } 117 \text { (2018) } \\
012010\end{array}$ & $\begin{array}{l}\text { Air pollutants were monitored with the use of instruments which } \\
\text { are Rae System Multirae Lite Pumped (PGM-6208) to measure } \\
\text { indoor air quality while TSI } 8533 \text { Dusttrack Drx Desktop Aerosol } \\
\text { Monitor to measure outdoor air quality. In this work sampling was } \\
\text { replicated two times. According to this paper it is not only presents } \\
\text { the beneficial information for future research on methodologies }\end{array}$ \\
\hline
\end{tabular}




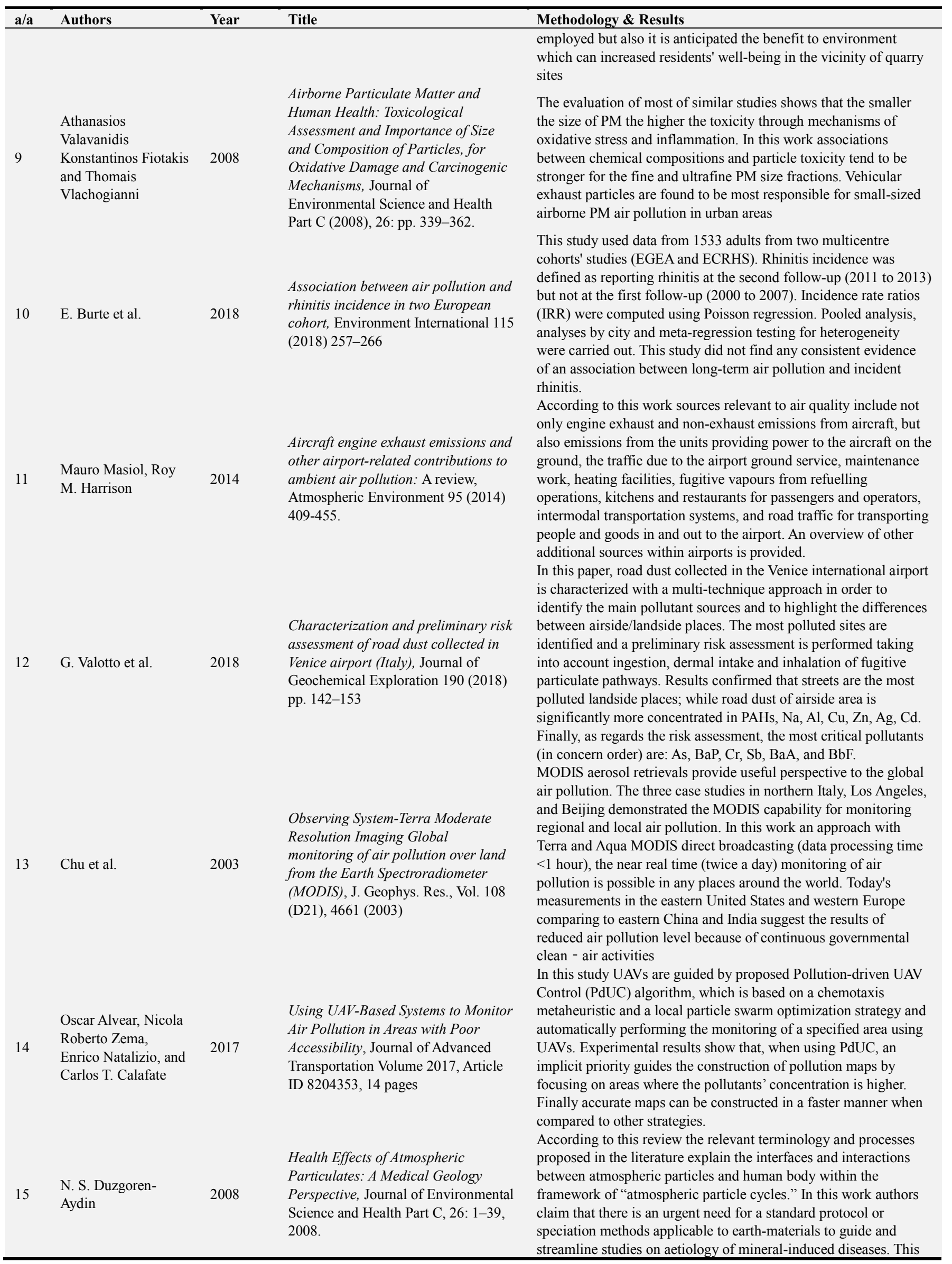




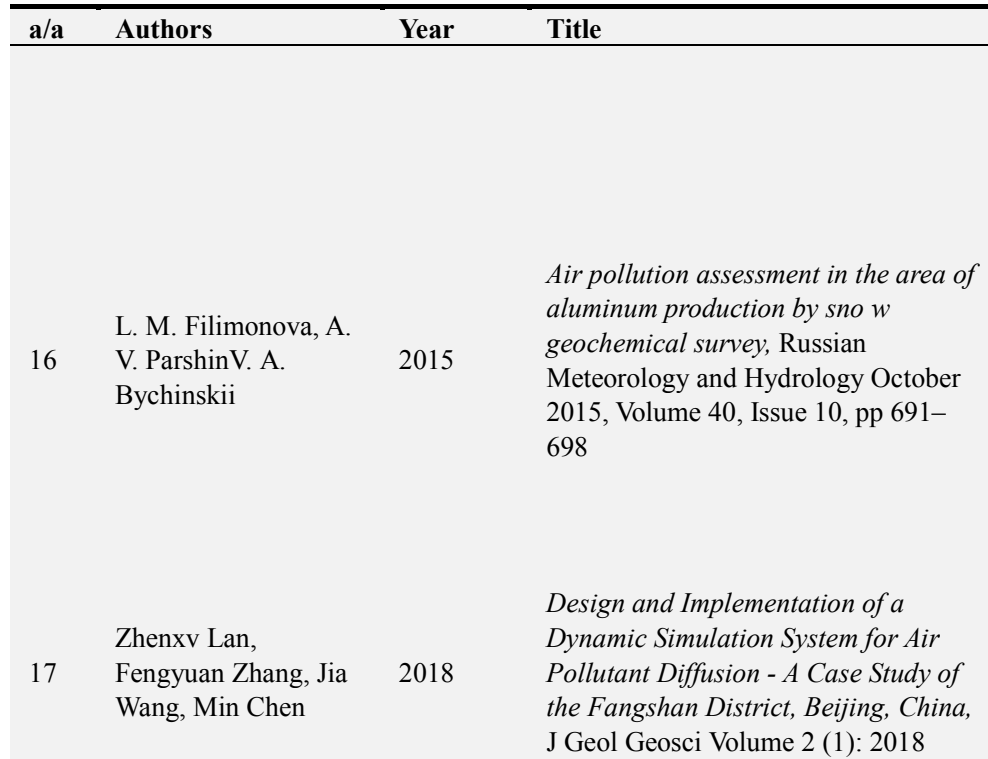

Mapping urban air pollution using GIS: a regression-based approach, Journal International Journal of Geographical Information Science Volume 11, 1997 - Issue 7

The earth, source of health and

H. Catherine W. Skinner introduction to medical geology. Annual Review of Earth and Planetary, Sciences 2007; 35: 177-213

Inmaculada Menendez et al.

Yong Zha, Jay Gao,

Influence of quarry mining dust on PM2.5 in a city adjacent to a limestone quarry: Seasonal characteristics and source contributions, Science of the Total Environment 550 (2016) pp. 940-949

Saharan dust and the impact on adult and elderly allergic patients: the effect of threshold values in the northern sector of Gran Canaria, Spain, International Journal of Environmental Health Research, 2017, 27: 2, 144 160

Normalized difference haze index: a new spectral index for monitoring urban air pollution. International Journal of Remote Sensing, Vol. 33, No. 1, 10 January 2012, pp. 309-321

\section{Methodology \& Results}

protocol or speciation methods should provide relevant procedures to determine the level and extent of physical, chemical and mineralogical heterogeneity of particulate matters as well as quantitative in-situ particulate characteristics. In this work the monitoring of the snow cover was conducted in the zone of the impact of the emission source (the Irkutsk Aluminium Smelter). The population of the town of Shelekhov will probably suffer from chronic diseases of the respiratory system. The dust-aerosol pollution of the Shelekhovskii industrial region forms the specific lithochemical anomaly with the area of about $70 \mathrm{~km} 2$. Its central part adjoins the Irkutsk Aluminum Smelter. The anomaly is represented by the set of litho-, chalco-, and siderophile elements forming contrast (relative to the background areas) associations.

In this study a simulation system platform for the diffusion process of atmospheric pollutants is designed and implemented, which has various functions including dynamic simulation display expression, GIS spatial analysis, spatial data processing, attribute information extraction and simulation result thematic mapping and export. The results show that the system provides significant decision-making guidance for effective urban air pollution warnings and the improvement of urban air quality In this study to determine the chemical composition of pollutants and the distance of their propagation on the territory under study in 2013 and 2014, ata from 80 of the monitoring sites were then used to construct a regression equation, on the basis of predictor environmental variables, and the resulting equation used to map air pollution across the study area. Results showed that the map produced extremely good predictions of monitored pollution levels, both for individual surveys and for the mean annual concentration. Though the accuracy of predictions for individual survey periods was more variable..

Geographical Information Systems (GIS) has become the technique with which geochemical and surficial topographic and any other geologic data can be linked to epidemiological data on disease and its distribution. Health impacts depend on bioavailability of hazardous materials or agents and their transfer to or into the human body. According this work the many and diverse human responses to different levels of chronic hazards plus patchy reporting of disease occurrences for individuals, communities, and countries limit the data available for constructing models capable of predicting thresholds or exposure levels to chronic hazards for an at-risk group of individuals or populations In this study the samples were subject for chemical analysis for dust-related species (Al, Si, Ca, Fe, Ti), tracer metals, carbon components and water-soluble ions. Seasonal variations of PM2.5 and its main chemical components were investigated. Air mass residence time (AMRT) analysis showed that northeast and southeast regions might be the major PM2.5 source during the sampling campaign. The findings of this study can be used to understand the characteristics of quarry mining dust and control strategies for PM2.5.

During 2010 and 2011, an epidemiological survey, in parallel with an air quality study, was conducted at the Dr Negrín hospital in Gran Canaria. In this study no statistically significant relations were found between the allergic control group, the emergency room admissions, pulmonary conditions, medication, and elevated Saharan dust levels

A new index called the normalized difference haze index (NDHI) was derived using moderate resolution imaging spectroradiometer (MODIS) data from winter 2008-2009 and in this study it was concluded that NDHI is a reliable indicator of air pollution. It can be used as a new method of effectively monitoring air pollution from remotely sensed data. 


\begin{tabular}{|c|c|c|c|}
\hline $\mathbf{a} / \mathbf{a}$ & Authors & Year & Title \\
\hline & & & $\begin{array}{l}\text { by particulate air pollution, Mutation } \\
\text { Research } 592 \text { (2005) pp. 119-137 }\end{array}$ \\
\hline
\end{tabular}

Methodology \& Results

models, cell culture experiments, and cell free systems that exposure to diesel exhaust and diesel exhaust particles causes oxidative DNA damage. In this study oxidative stress-induced DNA damage appears to an important mechanism of action of urban particulate air pollution. Related biomarkers and personal monitoring may be useful tools for risk characterization. The analysis is based on data collected by the American Cancer Society (ACS) as part of the Cancer Prevention Study II (CPS-II), an ongoing prospective mortality study of approximately 1.2 million adults. 18, 19 Individual participants were enrolled by ACS

C. A. Pope III, R. T. Burnett, M. J. Thun,

24 E. E. Calle, D. Krewski, K. Ito, G. D. Thurston pp. 791-800

Long-term ozone exposure and mortality. New Engl. J. Med. 360 (11), 1085-1095

Inhalation of fine particulate air pollution and ozone causes acute arterial vasoconstriction in healthy adults. Circulation 105 (13), pp 15341536. volunteers in the fall of 1982. Participants resided in all 50 states, the District of Columbia, and Puerto Rico, and were generally friends, neighbors, or acquaintances of ACS volunteers. The findings of this study provide the strongest evidence to date that long-term exposure to fine particulate air pollution common to many metropolitan areas is an important risk factor for cardiopulmonary mortality. Elevated fine particulate air pollution exposures were associated with significant increases in lung cancer mortality.

Exposure to pollutants such as airborne particulate matter and ozone has been associated with increases in mortality and hospital admissions due to respiratory and cardiovascular disease. These effects have been found in short-term studies, which relate day-today variations in air pollution and health, and long-term studies, which have followed cohorts of exposed individuals over time. In this study data collected for 1,042 lung cancer cases and 2,364 population controls included information on residence from 1955 to the end of follow-up for each individual, 1990-1995. Assessed ambient air concentrations of pollutants from road traffic and heating throughout the study area for three points in time (1960, 1970, and 1980) using reconstructed emission data for the index pollutants nitrogen oxides $(\mathrm{NOx} / \mathrm{NO} 2)$ and sulfur dioxide together with dispersion modeling. The results indicate that GIS can be useful for exposure assessment in environmental epidemiology studies, provided that detailed geographically related exposure data are available for relevant time periods

Modelling concentrations of fine particulate matter (PM2.5) and ozone $(\mathrm{O} 3)$ attributable to precursor emissions from individual airports in the United States, developing airport-specific health damage functions (deaths per 1000t of precursor emissions) and physically-interpretable regression models to explain variability in these functions. In this study authors applied the Community Multiscale Air Quality model using the Decoupled Direct Method to isolate PM2.5- or O3-related contributions from precursor pollutants emitted by 66 individual airports. Findings reinforce the importance of location- and source-specific health damage functions in design of health-maximizing emissions control policies.

In this study, data from the study cohort of the American Cancer Society Cancer Prevention Study II were correlated with airpollution data from 96 metropolitan statistical areas in the United States. Data were analyzed from 448,850 subjects, with 118,777 deaths in an 18-year follow-up period. Associations between ozone concentrations and the risk of death were evaluated with the use of standard and multilevel Cox regression models. In this large study, was not able to detect an effect of ozone on the risk of death from cardiovascular causes when the concentration of PM2.5 was taken into account. sure to ozone on the risk of death from respiratory causes.

Twenty-five healthy adults underwent a randomized, double-blind, crossover study comparing the vascular response to the 2-hour inhalation of approximately $150 \mathrm{microg} / \mathrm{m}$ (3) of concentrated ambient fine particles (CAP) plus ozone (120 ppb) versus the response to the inhalation of filtered airShort-term inhalation of fine particulate air pollution and ozone at concentrations that occur in the urban environment causes acute conduit artery vasoconstriction 


\begin{tabular}{|c|c|c|c|c|}
\hline $\mathbf{a} / \mathbf{a}$ & Authors & Year & Title & Methodology \& Results \\
\hline 30 & $\begin{array}{l}\text { Colin Wong and } \\
\text { Rachel Wyles }\end{array}$ & 2012 & $\begin{array}{l}\text { Mapping concentrations of airborne } \\
\text { matter to quantify the fugitive } \\
\text { emissions discharge rate from a } \\
\text { landfill, Greenhouse Gas } \\
\text { Measurement \& Management } 2 \mid 2012 \\
\mid \text { 50-60 }\end{array}$ & $\begin{array}{l}\text { In this work the application of the AMM method involved the } \\
\text { measurement of wind velocity at the site, mounting a GPS and a } \\
\text { fast, high-resolution concentration measurement instrument on a } \\
\text { helicopter and then travelling through the plume along a } \\
\text { measurement path, with each sampling run at different elevations, } \\
\text { was conducted. The methane concentration data were also } \\
\text { projected with the wind flow direction onto a flux plane and, when } \\
\text { the wind speed was applied and an adjustment made for the } \\
\text { background concentrations, the net mass flow rate of methane } \\
\text { across the measurement surface and the mass emission discharge } \\
\text { rate from the fugitive emission source were calculated to be } 2.3 \\
\mathrm{~g} / \mathrm{s} \text {. }\end{array}$ \\
\hline
\end{tabular}

\subsection{Related Work for Surface and Underground Water Bodies}

The majority of the methods reviewed in the present study refer to monitoring, sampling and measuring of fertilizers, pesticides, insecticides $[3,37,52-54,57,60,61]$ as is presented in Table 2. There are also scientific articles and research data which make reference to industrial effluents, waste water and solid waste treatment monitoring [39-50, 7177]. Other methods of sampling techniques and analysis for the monitoring of water bodies focus on the chemical elements (Emergent Contaminants ECs) [3, 4, 50-61, 65-70, 78-81].

Table 2. Literature review of methods related to water bodies.

\begin{tabular}{|c|c|c|c|c|}
\hline $\mathbf{a} / \mathbf{a}$ & Authors & Year & Title & Methodology \& Results \\
\hline 1 & $\begin{array}{l}\text { Iturburu, F. G., } \\
\text { Calderon, G., } \\
\text { Amé, M. V., \& } \\
\text { Menone, M. L. }\end{array}$ & 2019 & $\begin{array}{l}\text { Ecological Risk Assessment } \\
\text { (ERA) of pesticides from } \\
\text { freshwater ecosystems in the } \\
\text { Pampas region of Argentina: } \\
\text { Legacy and current use } \\
\text { chemicals contribution. } \\
\text { Science of The Total } \\
\text { Environment, 691, 476-482. }\end{array}$ & $\begin{array}{l}\text { Based on a concentration addition model, this study developed an Ecological } \\
\text { Risk Assessment (ERA) of pesticides from freshwater ecosystems in the } \\
\text { Pampas region. For this purpose, reported pesticides concentrations available in } \\
\text { public bibliography and a Risk Quotients (RQs) approach were used. A } \\
\text { cumulative risk map was established to display RQs for current use pesticides } \\
\text { (CUPs) and legacy chemicals. The present study is the first attempt to develop } \\
\text { an ERA in surface water of the Pampas region of Argentina and it provides a } \\
\text { starting point for a more comprehensive pesticides monitoring and a further risk } \\
\text { assessment program. }\end{array}$ \\
\hline 2 & $\begin{array}{l}\text { Boone, J. S., Vigo, } \\
\text { C., Boone, T., } \\
\text { Byrne, C., } \\
\text { Ferrario, J., } \\
\text { Benson, R.,.. \& } \\
\text { Glassmeyer, S. T. }\end{array}$ & 2019 & $\begin{array}{l}\text { Per-and polyfluoroalkyl } \\
\text { substances in source and } \\
\text { treated drinking waters of the } \\
\text { United States. Science of the } \\
\text { Total Environment, } 653,359 \text { - } \\
369 \text {. }\end{array}$ & $\begin{array}{l}\text { During this work seventeen per- and polyfluoroalkyl substances (PFAS) were } \\
\text { monitored by LC/MS/MS. Twenty-five paired source and treated drinking } \\
\text { waters were sampled. All } 50 \text { samples had detectable PFAS; one exceeded health } \\
\text { advisory guidelines. Distinctive PFAS patterns were observed for two large } \\
\text { river systems. The perfluorooctanoic acid (PFOA) and perfluorooctanesulfonic } \\
\text { acid (PFOS) concentrations in the treated drinking water are compared to the } \\
\text { existing US Environmental Protection Agency's PFOA and PFOS drinking } \\
\text { water heath advisory of } 70 \text { ng/L for each chemical or their sum one DWTP } \\
\text { exceeded the threshold. Six of the } 25 \text { DWTPs were along two large rivers. The } \\
\text { DWTPs within each of the river systems had specific PFAS profiles, with the } \\
\text { three DWTPs from one river being dominated by PFOA, while three DWTPs } \\
\text { on the second river were dominated by perfluorobutyric acid (PFBA). }\end{array}$ \\
\hline 3 & $\begin{array}{l}\text { E. N. Papadakis } \\
\text { et. al. }\end{array}$ & 2015 & $\begin{array}{l}\text { A pesticide monitoring survey } \\
\text { in rivers and lakes of } \\
\text { northern Greece and its } \\
\text { human and ecotoxicological } \\
\text { risk assessment, } \\
\text { Ecotoxicology and } \\
\text { Environmental Safety } 116 \\
\text { (2015) 1-9 }\end{array}$ & $\begin{array}{l}\text { A total of } 416 \text { samples were collected over a } 1.5 \text {-year sampling period } \\
\text { (September } 1999 \text { - February } 2001 \text { ) from six rivers and ten lakes, in the present } \\
\text { work. The water samples were analyzed with an off-line solid phase extraction } \\
\text { technique coupled with a gas chromatography ion trap mass spectrometer using } \\
\text { an analytical method for } 147 \text { pesticides and their metabolites, including } \\
\text { organochlorines, organophosphates, triazines, chloroacetanilides, pyrethroids, } \\
\text { carbamates, phthalimides and other pesticides (herbicides, insecticides and } \\
\text { fungicides). Based on the pesticide survey results, a human health carcinogenic } \\
\text { and non-carcinogenic risk assessment was conducted for adults and children. } \\
\text { Concentrations of six pesticides were above the maximum allowable limit of } \\
0.1 \mu \mathrm{g} / \mathrm{L} \text { set for drinking water. The coupling of monitoring data to probabilistic } \\
\text { human and ecotoxicological risk estimates could find use by Greek regulatory } \\
\text { authorities, proposing effective pollution management schemes. }\end{array}$ \\
\hline 4 & $\begin{array}{l}\text { Tengku Ibrahim, } \\
\text { F. Othman and N. } \\
\text { Z. Mahmood }\end{array}$ & 2017 & $\begin{array}{l}\text { Assessment of water quality of } \\
\text { Sembilang River receiving } \\
\text { effluent from controlled } \\
\text { municipal solid waste (MSW) } \\
\text { landfill in Selangor, IOP } \\
\text { Conf. Series: Materials } \\
\text { Science and Engineering } 210 \\
\text { (2017) } 012019\end{array}$ & $\begin{array}{l}\text { The main objective of this study was to investigate the effect on water quality } \\
\text { of Sembilang River that receives effluent from the nearby landfill. In this study. } \\
\text { Samples of water from ten sampling stations starting from the upstream to } \\
\text { downstream of Sembilang River, were analyzed. The water quality was } \\
\text { evaluated by the Water Quality Index (WQI) depending on in-situ and } \\
\text { laboratory analysis. } 11 \text { water quality variables are selected for the quality } \\
\text { assessment; temperature, pH, turbidity, salinity, dissolved oxygen, biochemical } \\
\text { oxygen demand, chemical oxygen demand, total suspended solid, ammoniacal }\end{array}$ \\
\hline
\end{tabular}




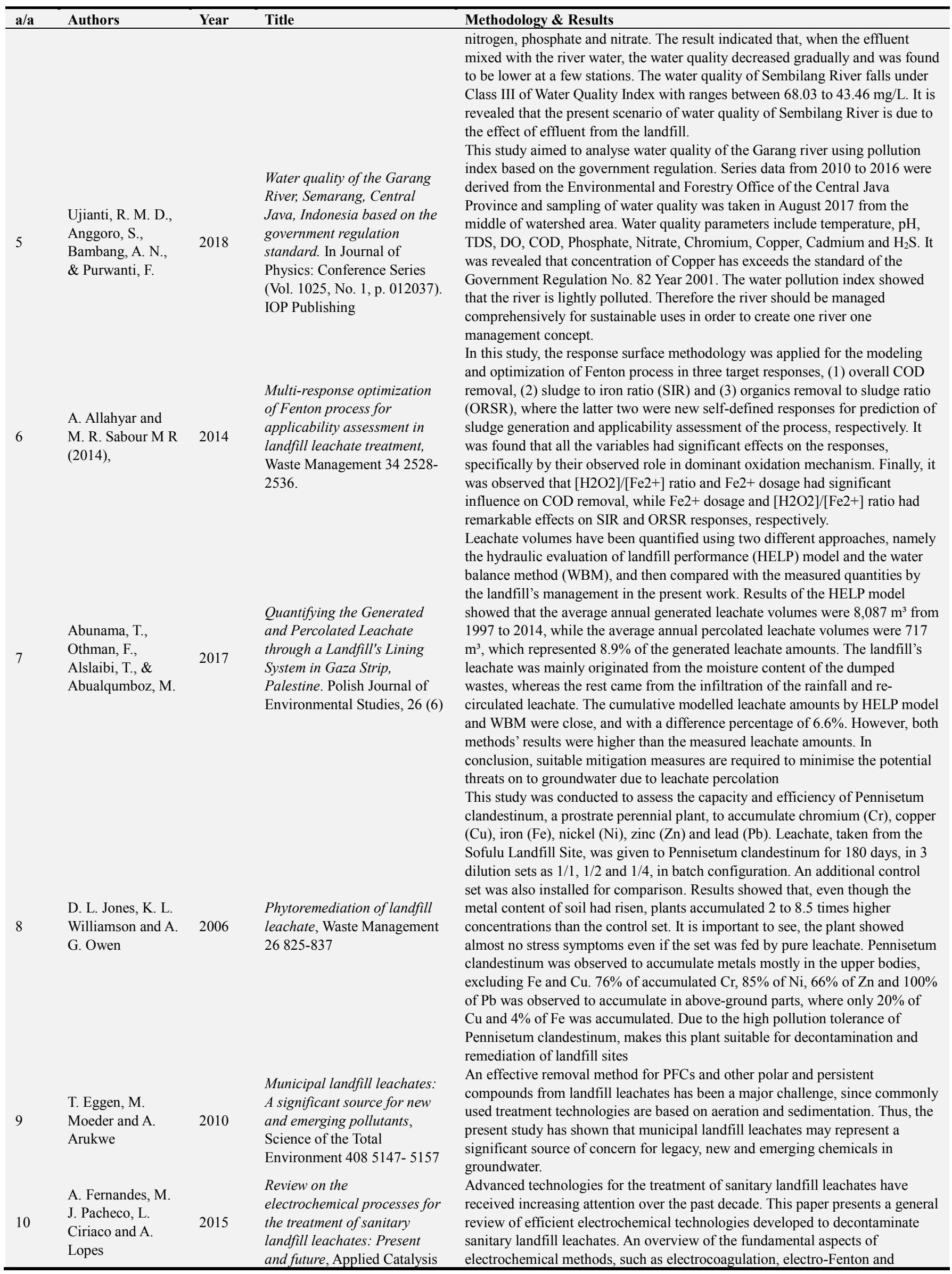




\begin{tabular}{|c|c|c|c|}
\hline $\mathbf{a} / \mathbf{a}$ & Authors & Year & Title \\
\hline & & & $\begin{array}{l}\text { B: Environmental 176-7 183- } \\
200\end{array}$ \\
\hline 11 & $\begin{array}{l}\text { Muhammad } \\
\text { Umar, H. Abdul } \\
\text { Aziz and M. S. } \\
\text { Yusoff }\end{array}$ & 2010 & $\begin{array}{l}\text { Variability of parameters } \\
\text { involved in leachate pollution } \\
\text { index and determination of } \\
\text { LPI from four landfills in } \\
\text { Malaysia, International } \\
\text { Journal of Chemical } \\
\text { Engineering 1-6. }\end{array}$ \\
\hline 12 & $\begin{array}{l}\text { N. Yusof, A. } \\
\text { Haraguchi, M. A. } \\
\text { Hassan, M. R. } \\
\text { Othman, M. } \\
\text { Wakisaka and Y. } \\
\text { Shiraj }\end{array}$ & 2009 & $\begin{array}{l}\text { Measuring organic carbon, } \\
\text { nutrients and heavy metals in } \\
\text { rivers receiving leachate from } \\
\text { controlled and uncontrolled } \\
\text { municipal solid waste (MSW) } \\
\text { landfills, Waste Management } \\
2666-2680\end{array}$ \\
\hline
\end{tabular}

\section{Methodology \& Results}

electrochemical oxidation, is provided and updated information on the application of these technologies to sanitary landfill leachates is given. The effect of the main process variables of these electrochemical technologies in the sanitary landfill leachates treatment effectiveness is discussed and a critical analysis of the prime benefits and drawbacks of its application is made. Leachate pollution index (LPI) provides an overall pollution potential of a landfill site. The parameters required to calculate LPI from a landfill site are discussed in terms of their variations over time, and their significance has been highlighted in the context of LPI. The LPI values of two semiaerobic and two anaerobic landfill sites in Malaysia have been calculated in this study. Pulau Burung Landfill Site (PBLS) was found to have the highest LPI score while Ampang Jajar Landfill Site (AJLS) showed the lowest LPI as compared to other landfills. It is concluded that LPI value can be used as a tool to assess the leachate pollution potential from landfill sites particularly at places where there is a high risk of leachate migration and pollution of groundwater. In this study, leachates from three different types of landfills, namely active uncontrolled, active controlled and closed controlled, were characterized, and their relationships with river water chemistry were examined monthly for a year. The influence of leachate on river water chemistry from each type of landfill depended on many factors, including the presence of a leachate control mechanism, leachate characteristics, precipitation, surface runoff and the applied treatment. Improper treatment practice led to high levels of some contaminants in the stream near the closed controlled landfill. Meanwhile, the active controlled landfill, which was located near the coastline, was exposed to the risk of contamination resulting from the pyrite oxidation of the surrounding area.

In order to assess the heavy metal pollution and provide the base information in this region for The Twelfth Five-Year Plan, contents and fractions of four heavy metals $(\mathrm{Cd}, \mathrm{Cu}, \mathrm{Pb}$ and $\mathrm{Zn})$ covering both sediments and soils were analyzed to

Assessment of Heavy Metal Contamination in the Surrounding Soils and

Jiang M, Zeng G, Zhang C, Ma X, Chen $\mathrm{M}$, et al. Surface Sediments in Xiawangang River, Qingshuitang District, PLoS ONE 8 (8): e71176

Pradip Kumar Maurya and D. S. 2018 Malik
Bioaccumulation of heavy metals in tissues of selected fish species from Ganga river, India, and risk assessment for human health, Human and Ecological Risk Assessment

Characterization of Missouri surface waters near point sources of pollution reveals potential novel atmospheric route of exposure for bisphenol $A$ and wastewater hormonal activity pattern, Science of the Total Environment 524-525 (2015) 384-393 study their contamination state. Three different indexes were applied to asses the pollution extent. The results showed this area was severely polluted by the four heavy metals, and the total concentrations exceeded the Chinese environmental quality standard for soil, grade III, especially for Cd. Moreover, $\mathrm{Cd}$, rated as being in high risk, had a high mobility as its great contents of exchangeable and carbonates fractions in spite of its relative low content. Regression analysis revealed clay could well explain the regression equation for $\mathrm{Cd}, \mathrm{Cu}$ and $\mathrm{Zn}$ while $\mathrm{pH}$ and sand could significantly interpret the regression equation for $\mathrm{Pb}$. Moreover, there was a significant correlation between Nonresidual fraction and Igeo for all the four metals. Correlation analysis showed four metals maybe had similar pollution sources.

Authors here measured the concentration of $\mathrm{Cd}, \mathrm{Cr}, \mathrm{Pb}, \mathrm{Cu}$, and $\mathrm{Zn}$ in various fish tissues (muscle, gills, and liver) of 18 fish species collected from Ganga river. It is the survey regarding metal concentration in fish tissues increasing day by day. The metal concentration in different fish tissues varied on the following range. Despite lower estimated daily intake (EDI) of fish in the area (per recommended daily allowance guidelines), values of daily average consumption were lower than the recommended values by FAO/WHO/EFSA, and in fish samples these were below the provisional permissible levels for human consumption. The continuous exposure to heavy metals has been linked to the development of mental retardation, kidney damage, various cancers, and even death in instances of very high exposure in human body!

This study assessed water quality at several sites across Missouri (near wastewater treatment plants and airborne release sites of bisphenol A) based on hormone receptor activation potencies and chemical concentrations present in the surface water. Was hypothesized that bisphenol A and ethinylestradiol would be greater in water near permitted airborne release sites and wastewater treatment plant inputs, respectively, and that these two compounds would be responsible for the majority of activities in receptor-based assays conducted with water collected near these sites. Estrogen and androgen receptor activities of surface water samples were predictive of wastewater input, although the lower sensitivity of the ethinylestradiol ELISA relative to the very high sensitivity of the bioassay approaches did not allow a direct comparison. Wastewater-influenced sites also had elevated anti-estrogenic and antiandrogenic equivalence, while sites without wastewater discharges exhibited no antagonist activities.

An extensive water sampling was carried out from stream tributaries, open channels, drainages, and seepages during the snow-melting season in 2001. 


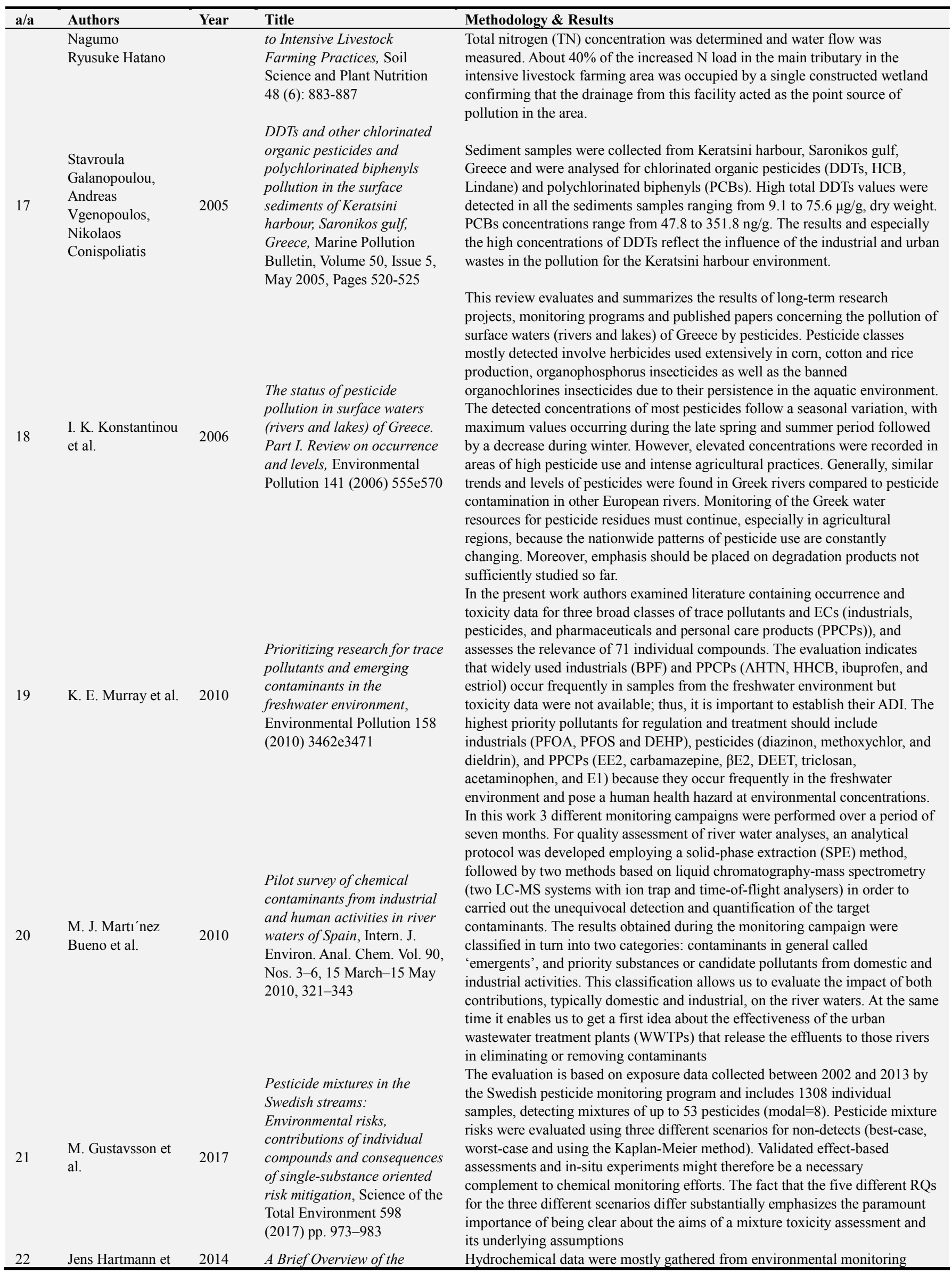




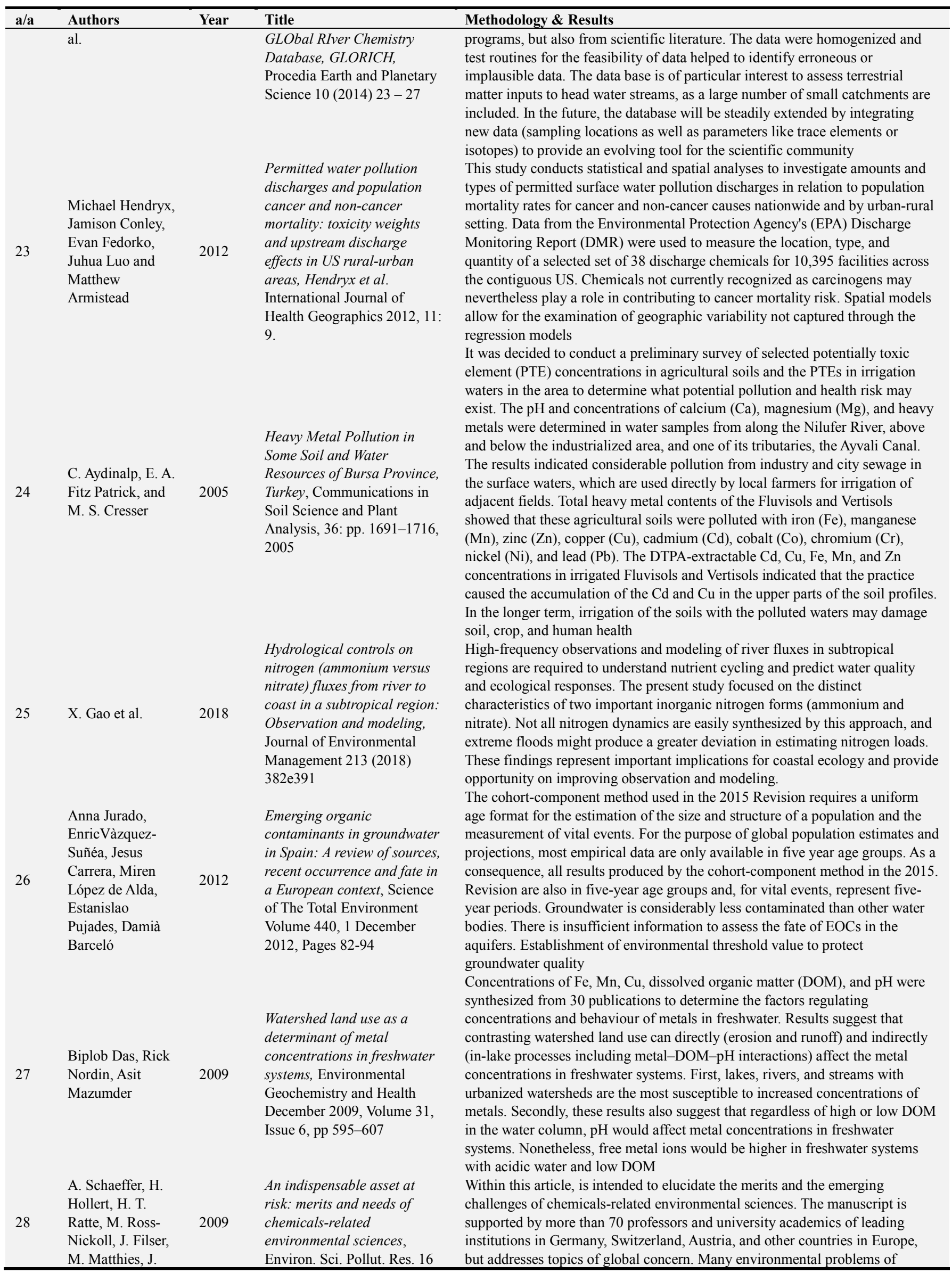




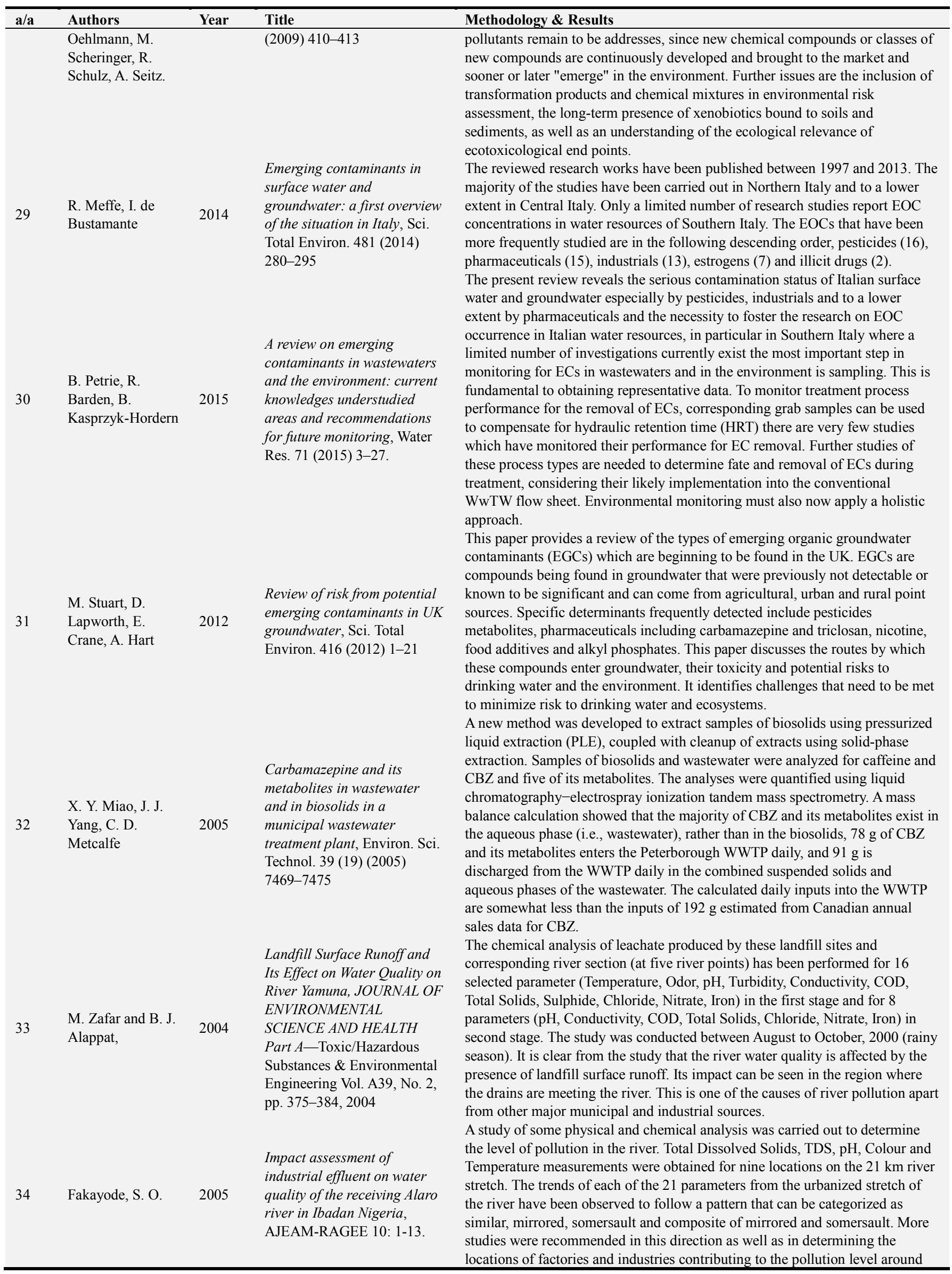




\begin{tabular}{|c|c|c|c|c|}
\hline $\mathbf{a} / \mathbf{a}$ & Authors & Year & Title & Methodology \& Results \\
\hline 35 & $\begin{array}{l}\text { Kanu, Ijeoma and } \\
\text { Achi, O. K. }\end{array}$ & 2011 & $\begin{array}{l}\text { Industrial Effluents and Their } \\
\text { Impact on Water Quality of } \\
\text { Receiving Rivers in Nigeria, } \\
\text { Journal of Applied } \\
\text { Technology in Environmental } \\
\text { Sanitation, } 1 \text { (1): } 75-86\end{array}$ & $\begin{array}{l}\text { Ewupe and their effluent disposal programs will need to be ascertained } \\
\text { With competing demands on limited water resources, awareness of the issues } \\
\text { involved in water pollution, has led to considerable public debate about the } \\
\text { environmental effects of industrial effluents discharged into aquatic } \\
\text { environments. Industrial effluents are characterized by their abnormal turbidity, } \\
\text { conductivity, chemical oxygen demand (COD), total suspended solids (TSS), } \\
\text { biological oxygen demand (BOD), and total hardness. Waste effluents rich in } \\
\text { decomposable organic matter, is the primary cause of organic pollution. Waste } \\
\text { waters from textile, brewery, food and beverages, paper, pulp and palm oil } \\
\text { industries, the cases chosen, are believed to give a broad outline of industrial } \\
\text { wastes as well as disposal problems. } \\
\text { Policy-makers and scientists will have to cooperate to create an initial } \\
\text { groundwater emerging pollutant priority list, to answer at consumer demands }\end{array}$ \\
\hline 36 & $\begin{array}{l}\text { Lucrezia } \\
\text { Lamastra, Matteo } \\
\text { Balderacchi, } \\
\text { Marco Trevisan }\end{array}$ & 2016 & $\begin{array}{l}\text { Inclusion of emerging organic } \\
\text { contaminants in groundwater } \\
\text { monitoring plans, MethodsX } \\
\text { Volume } 3,2016 \text {, Pages } 459- \\
476\end{array}$ & $\begin{array}{l}\text { for safety and to the lack of conceptual models for emerging pollutants in } \\
\text { groundwater. This paper starts from the current regulatory framework and from } \\
\text { the literature overview to explain how the missing conceptual model for OWCs } \\
\text { could be developed. In the present paper the attention was focused on the case } \\
\text { of OWCs using simplified pathways: from households to WWTPs to rivers and } \\
\text { to groundwater; from bio solids, greywater, and livestock manure to soils and } \\
\text { groundwater. }\end{array}$ \\
\hline 37 & $\begin{array}{l}\text { Nubi, O. A. } 1 \\
\text { Osibanjo, O. } \\
\text { Nubi, A. T. }\end{array}$ & 2008 & $\begin{array}{l}\text { Impact assessment of } \\
\text { dumpsite leachate on the } \\
\text { qualities of surface water and } \\
\text { sediment of river Eku, Ona- } \\
\text { Ara local government, Oyo } \\
\text { State, Nigeria. Science World } \\
\text { Journal } 3 \text { (3): } 17-20\end{array}$ & $\begin{array}{l}\text { The river under study was divided into three regions for sample collection. The } \\
\text { collected samples were transported back to the laboratory the samples were } \\
\text { kept in an ice cooler and upon arrival they were refrigerated at } 4{ }^{\circ} \mathrm{C} \text { and } \\
\text { analysed within } 1 \mathrm{wk} \text {. Except for nitrate determination that was carried out } \\
\text { using phenoldisulphonic acid spectophotometric method (Michael 1950), } \\
\text { APHA-AWWA-WPCF method (1981) was used for all the parameters studied } \\
\text { on water samples. The IITA (1979) method was used for determination of heavy } \\
\text { metals in sediment samples. In all the parameter levels, the values at US } 2 \text { were } \\
\text { found to be higher than US1. This may be due to the back flow movement } \\
\text { observed between US2 and POD during leachate intrusion. The contributions of } \\
\text { heavy metals to the surface water by the leachate appeared to be slight. } \\
\text { However, according to this work higher values of Lead and Zinc were observed } \\
\text { at US1. The source of this may be from vehicular emission along the course of } \\
\text { the river in the upstream region. }\end{array}$ \\
\hline 38 & $\begin{array}{l}\text { Udiba U. U., } \\
\text { Gauje Balli, } \\
\text { Ashade N. O., } \\
\text { Ade-Ajayi F. A., } \\
\text { Okezie V. C., Aji } \\
\text { B. M. and Agboun } \\
\text { T. D. T. }\end{array}$ & 2014 & $\begin{array}{l}\text { An assessment of the heavy } \\
\text { metal status of River Galma } \\
\text { around Dakace industrial } \\
\text { layout, Zaria, Nigeria, Merit } \\
\text { Research Journal of } \\
\text { Environmental Science and } \\
\text { Toxicology (ISSN: 2350- } \\
\text { 2266) Vol. } 2 \text { (8) pp. 176-184, } \\
\text { November, } 2014\end{array}$ & $\begin{array}{l}\text { Four sampling stations were established, with sampling station } 1 \text { (control) } \\
\text { upstream before effluent discharged points from the industrial layout. Cadmium } \\
(\mathrm{Cd}) \text { Manganese }(\mathrm{Mn}) \text {, Chromium }(\mathrm{Cr}) \text { and Cobalt }(\mathrm{Co}) \text { concentrations were } \\
\text { analysed using Schimadzu atomic absorption spectrophotometer (modelAA- } \\
6800 \text {, Japan) after wet digestion. Surface water temperatures were found to be } \\
\text { above WHO standards for domestic water supply. Use of the water under study } \\
\text { for domestic and which depicts polluted water. agricultural purposes thus poses } \\
\text { serious toxicological risk. }\end{array}$ \\
\hline
\end{tabular}

Udiba U. U., Anyanwu Stella, Gauje Balli, Dawaki S. I., Oddy-Obi I. C., Agboun T. D. T.

Toxicity Potential of Allium cepa L. as a Bioindicator of Heavy Metal Pollution Status of River Galma Basin Around Dakace Industrial Layout, Zaria, Nigeria, International Journal of Biological Sciences and Applications 2015; 2 (6): 76-85

Modeling increased riverine nitrogen export: Source

$40 \quad$ D. Yu et al. tracking and integrated watershed-coast management, Marine Pollution Bulletin 101 (2015) 642-652

Monitoring emerging contaminants in the drinking water of Milan and assessment of the human risk, Hygiene and Environmenta Health 221 (2018) 451-457
In this study the significant positive correlation observed between lead and chromium, lead and nickel, and between chromium and nickel indicates that as the concentration of lead in onions bulbs increases the concentrations of chromium and nickel also increases suggesting that same source is responsible for the presence of these metals at the concentrations determined. Use of the water under study for domestic and agricultural purposes thus poses serious toxicological risk.

The global NEWS model was calibrated and then used to quantify the long term trend of dissolved inorganic nitrogen (DIN) export from two tributaries of Jiulong River (SE China). Scenario analysis and source tracking suggest that reductions of anthropogenic $\mathrm{N}$ inputs of at least $30 \%$ in the North River (emphasis on fertilizer and manure) and $50 \%$ in the West River (emphasis on fertilizer) could significantly improve water quality and mitigate eutrophication in both river and coastal waters.

In this study Human Risk Assessment (HRA) was conducted by comparing the measured concentrations with drinking water thresholds from guidelines or calculated in this study; first considering the exposure to each single EC and then the entire mixture. Thirteen ECs were measured. The results of the HRA excluded any risks for consumers in each scenario considered. This is one of the most comprehensive studies assessing the presence of a large number of ECs in the whole drinking water network of a city, and the risks for human health. 


\begin{tabular}{|c|c|c|c|c|}
\hline $\mathbf{a} / \mathbf{a}$ & Authors & Year & Title & Methodology \& Results \\
\hline & et al. & & $\begin{array}{l}\text { contaminants of emerging } \\
\text { concern in source and treated } \\
\text { drinking waters of the United } \\
\text { States, Science of the Total } \\
\text { Environment 581-582 (2017) } \\
\text { pp. 909-922 } \\
\text { Occurrence of }\end{array}$ & $\begin{array}{l}\text { plants (DWTPs) were analysed as part of a two-phase study to determine } \\
\text { whether chemical and microbial constituents, many of which are considered } \\
\text { contaminants of emerging concern, were detectable in the waters. The data } \\
\text { collected as part of this project will be used to help inform evaluation of } \\
\text { unregulated contaminants in surface water, groundwater, and drinking water. }\end{array}$ \\
\hline 43 & $\begin{array}{l}\text { Christina I. } \\
\text { Nannou, Christina } \\
\text { I. Kosma and } \\
\text { Triantafyllos A. } \\
\text { Albanis }\end{array}$ & 2014 & $\begin{array}{l}\text { pharmaceuticals in surface } \\
\text { waters: analytical method } \\
\text { development and } \\
\text { environmental risk } \\
\text { assessment, International } \\
\text { Journal of Environmental } \\
\text { Analytical Chemistry, 14th } \\
\text { Symposium on Chemistry and } \\
\text { Fate of Modern Pesticides, } \\
\text { Ioannina, Greece (18-21 } \\
\text { September 2014). }\end{array}$ & $\begin{array}{l}\text { The method developed in this study was applied for the analysis of } \\
\text { pharmaceutical residues in surface waters from different sampling points along } \\
\text { the aquatic systems of Lake Pamvotis and the River Kalamas, close to the city } \\
\text { of Ioannina (Epirus, Greece), while the monitoring programme was carried out } \\
\text { during the four seasons of the year. The results denoted a possible threat for the } \\
\text { aquatic environment, rendering in this way the RQ method as a helpful tool for } \\
\text { a first approach. Extensive study is needed for triclosan, salicylic acid, } \\
\text { sulfamethoxazole and erythromycin in order to better correlate their occurrence } \\
\text { and potential toxic effects in aquatic life and humans. }\end{array}$ \\
\hline 44 & $\begin{array}{l}\text { J. Robles-Molina, } \\
\text { F. J. Lara-Ortega, } \\
\text { B. Gilbert-López, } \\
\text { J. F. García-Reyes } \\
\text { and A. Molina- } \\
\text { Díaz, J. } \\
\text { Chromatogr }\end{array}$ & 2014 & $\begin{array}{l}\text { Multi-residue method for the } \\
\text { determination of over } 400 \\
\text { priority and emerging } \\
\text { pollutants in water and } \\
\text { wastewater by solid-phase } \\
\text { extraction and liquid } \\
\text { chromatography-time-of- } \\
\text { flight mass spectrometry, } \\
\text { Journal of Chromatography A } \\
\text { Volume } 1350 \text {, } 11 \text { July } 2014 \text {, } \\
\text { Pages } 30-43 \text { A } 1350,30 \\
\text { (2014). }\end{array}$ & $\begin{array}{l}\text { This article describes the development and validation of a liquid } \\
\text { chromatography high-resolution mass spectrometry method for the } \\
\text { simultaneous determination of over } 400 \text { multi-class priority and emerging } \\
\text { pollutants with different physicochemical properties in environmental waters } \\
\text { (surface water and wastewater). The proposed approach is based on the use of a } \\
\text { database consisting of retention time/exact mass (of selected ions) pairs } \\
\text { implemented with specific software for data analysis. The overall method } \\
\text { performance was satisfactory with limits of quantification lower than } 10 \mathrm{ngL} \text { (- } \\
\text { 1) for the } 44 \% \text { of studied compounds. Recoveries between } 50 \% \text { and } 130 \% \text { were } \\
\text { obtained for the } 65 \% \text { of the analytes. This developed method was applied for } \\
\text { the determination of target analytes in real surface water and wastewater } \\
\text { samples. }\end{array}$ \\
\hline
\end{tabular}

\subsection{Related Work for Soil Pollution}

The majority of the methods referred in the present study, as is presented in Table 3, investigate the pollution from use of agricultural fertilizers and organic pollutants, [82, 86, 87], heavy metals (HMs) [83, 85, 88, 91-94].

Table 3. Literature review of methods related to soil pollution.

\begin{tabular}{|c|c|c|c|c|}
\hline $\mathbf{a} / \mathbf{a}$ & Authors & Year & Title & Methodology \& Results \\
\hline 1 & Finkelman, R. B. & 2019 & $\begin{array}{l}\text { The influence of clays on } \\
\text { human health: A medical } \\
\text { geology perspective. Clays and } \\
\text { Clay Minerals, } 67 \text { (1), 1-6. }\end{array}$ & $\begin{array}{l}\text { Humanoids have been ingesting clay for at least two million years to ease } \\
\text { indigestion and counteract poisons. Some additional benefits may accrue from } \\
\text { eating clays such as providing some nutrients but these benefits are far } \\
\text { outweighed by the likely negative consequences such as tissue abrasion, } \\
\text { intestinal blockage, anemia, exposure to pathogens and toxic trace elements, } \\
\text { and potassium overdose. Inhalation of airborne minerals including clays has } \\
\text { impacted the heath of millions. In South Africa, clay-poor soils yield crops } \\
\text { lacking in essential nutrients and may be the principal cause of Msileni joint } \\
\text { disease. Clearly, a detailed knowledge of the clays in the environment can } \\
\text { have significant benefits to human health and wellbeing. }\end{array}$ \\
\hline 2 & $\begin{array}{l}\text { Cupit M, Larsson } \\
\text { O, de Meeûs C, } \\
\text { Eduljee GH, } \\
\text { Hutton MC. }\end{array}$ & 2002 & $\begin{array}{l}\text { Assessment and management } \\
\text { of risks arising from exposure } \\
\text { to cadmium in fertilisers - I,/ } \\
\text { The Science of the Total } \\
\text { Environment } 291 \text { (2002) 167- } \\
187\end{array}$ & $\begin{array}{l}\text { A risk assessment protocol has been developed for use by individual EU } \\
\text { Member States with appropriate selection of input data, to assess the risks to } \\
\text { humans and the environment arising from exposure to cadmium in fertilisers. } \\
\text { The protocol comprises of three modules: } 1 \text {. the accumulation module. 2. The } \\
\text { exposure module. } 3 \text {. The risk characterisation module. Particular risk groups } \\
\text { can be characterised, namely of: children; smokers; women with low iron } \\
\text { stores; consumers of food items with high cadmium content; and extreme } \\
\text { consumers of staple food items. At present, with the data available, it is not } \\
\text { possible to characterise risk groups in detail, either at EU level or at Member } \\
\text { State level. However, most Member States appear to have an average intake } \\
\text { of cadmium which is lower than the WHO's PTWI }\end{array}$ \\
\hline 3 & $\begin{array}{l}\text { Zhongmin Jial, } \\
\text { Siyue Li \& Li } \\
\text { Wang }\end{array}$ & 2018 & $\begin{array}{l}\text { Assessment of soil heavy } \\
\text { metals for eco-environment } \\
\text { and human health in a rapidly } \\
\text { urbanization area of the upper } \\
\text { Yangtze Basin, SCIEnTIfIC } \\
\text { Reports | (2018) 8: } 3256 \text { | DOI: } \\
\text { 10.1038/s41598-018-21569-6 }\end{array}$ & $\begin{array}{l}\text { Averages of HMs were far below grade II threshold level of the Chinese } \\
\text { Environmental Quality standards for soils, whereas Cd, As and Hg } \\
\text { considerably exceeded the local background values. EF suggested overall } \\
\text { moderate enrichments of Cd and Se, resulting in soils uncontaminated to } \\
\text { moderately contaminated with them. There were no significant carcinogenic } \\
\text { and non - carcinogenic risks for adults, children however showed significant } \\
\text { non - carcinogenic effect. Our first assessment provided important }\end{array}$ \\
\hline
\end{tabular}




\begin{tabular}{llll}
\hline a/a & Authors & Year & Title \\
\hline & & \\
& & \\
& & \\
& & Association between heavy \\
& & metal and metalloid levels in \\
& Olivier Núñez et & \multirow{2}{*}{2017} & topsoil and cancer mortality in \\
& al. & & Spain, Environ Sci Pollut Res \\
& & & (2017) 24: 7413-7421.
\end{tabular}

Methodology \& Results

information for policy making to reduce the potential effects of soil

contamination on human and eco-environment

The aim of this study was to assess the possible association between heavy metal and metalloid levels in topsoil (upper soil horizon) and cancer mortality in mainland Spain. The elements included were determined by ICP-MS at 13,317 sampling points. To estimate the effect of heavy metal levels in topsoil composition on mortality, we fitted Besag, York and Mollié models, which included each town's factor scores as the explanatory variable. Integrated Nested Laplace The results showed an association between trace contents of heavy metals and metalloids in topsoil and mortality due to tumors of the digestive system in mainland Spain. The results support the interest of inclusion of heavy metal levels in topsoil as a hypothesis in analytical epidemiological studies using biological markers of exposure to heavy metals and metalloids.

In order to assess the heavy metal pollution and provide the base information in this region for The Twelfth Five-Year Plan, contents and fractions of four heavy metals $(\mathrm{Cd}, \mathrm{Cu}, \mathrm{Pb}$ and $\mathrm{Zn})$ covering both sediments and soils were

Jiang M, Zeng

G., Zhang C., Ma

X., Chen M., et

al.

Concentrations of Trace Metals in Selected Land Uses of a Dry Zone Soil Catena of Sri Lanka, Tropical

Agricultural Research Vol. 25 (4): $512-522$ (2014)

Nisreen Tamimi, Dörte Diehl, Mohand Njoum, Amer Marei, Gabriele E. Schaumann

G. Tóth et al.

2016
Heavy metals in European soils: A geostatistical analysis of the FOREGS Geochemical database, Geoderma 148 (2008) 189-199
Effects of olive mill wastewater disposal on soil: Interaction mechanisms during different seasons, J. Hydrol.

Hydromech., 64, 2016, 2, 176 195

Heavy metals in agricultural soils of the European Union with implications for food safety, Environment International 88 (2016) 299309 analyzed to study their contamination state. Three different indexes were applied to assess the pollution extent. The results showed this area was severely polluted by the four heavy metals, and the total concentrations exceeded the Chinese environmental quality standard for soil, grade III, especially for $\mathrm{Cd}$. Moreover, $\mathrm{Cd}$, rated as being in high risk, had a high mobility as its great contents of exchangeable and carbonates fractions in spite of its relative low content. There was a significant correlation between Nonresidual fraction and Igeo for all the four metals. Correlation analysis showed four metals maybe had similar pollution sources.

This study was conducted to find out the present level of trace metals, their sources and the relationships among them in selected land uses. A Dry Zone soil catena consisting of uncultivated, paddy-cultivated and vegetablecultivated land uses was selected for this study. A total of 58 soil samples were collected on the basis of latin hypercube sampling approach. Soil samples were analyzed for the total concentrations of $\mathrm{Cd}, \mathrm{Cu}, \mathrm{Pb}, \mathrm{Ni}$ and $\mathrm{Zn}$. The PCA confirmed the contribution of anthropogenic factors on $\mathrm{Cd}$ levels observed in this Dry Zone soil catena. The PCA indicated that $\mathrm{Cu}, \mathrm{Zn}$ and $\mathrm{Pb}$ would have originated from the mixed factor of natural and anthropogenic sources.

Choosing a different season for OMW application than the commonly practiced winter, may help avoid negative effects. However, understanding of the OMW-soil interaction during different seasons is still incomplete due to the lack of comparative data. The risks of groundwater contamination and persistent negative effects decrease with increasing time under conditions favoring biological activity. Therefore, OMW application in spring if improved by a careful irrigation is considered as the most suitable under semiarid conditions for clay loam soils.

The concentrations were mapped using regression-kriging (RK) and accuracy of predictions evaluated using the leave-one-out cross validation method. A large number of auxiliary raster maps (topographic indexes, land cover, geology, vegetation indexes, night lights images and earth quake magnitudes) were used to improve the predictions. Automation of the geostatistical mapping and use of auxiliary spatial layers opens a possibility to develop mapping systems that can automatically update outputs by including new field observations and higher quality auxiliary maps. This approach also demonstrates the benefits of organizing standardized joint European monitoring projects, in comparison to the merging of several national monitoring projects.

Quality of soil resources as defined by their potential impact on human health by propagation of harmful elements through the food chain has been poorly studied in Europe due to the lack of data of adequate detail and reliability. The European Union's first harmonized topsoil sampling and coherent analytical procedure produced trace element measurements from approximately 22,000 locations. This unique collection of information enables a reliable overview of the concentration of heavy metals, also referred to as metal (loid) s including $\mathrm{As}, \mathrm{Cd}, \mathrm{Cr}, \mathrm{Cu}, \mathrm{Hg}, \mathrm{Pb}, \mathrm{Zn}, \mathrm{Sb}$. $\mathrm{Co}$, and $\mathrm{Ni}$. In this article has been proposed that in some cases (e.g. $\mathrm{Hg}$ and $\mathrm{Cd}$ ) the high concentrations of soil heavy metal attributed to human activity can be detected at a regional level. While the immense majority of European agricultural land can be considered adequately safe for food production, an estimated $6.24 \%$ or $137,000 \mathrm{~km}$ needs 


\begin{tabular}{|c|c|c|c|c|}
\hline $\mathbf{a} / \mathbf{a}$ & Authors & Year & Title & Methodology \& Results \\
\hline 10 & P. Saikkonen & 2015 & $\begin{array}{l}\text { Production and Polluted Soil } \\
\text { in Urban Planning: The Case } \\
\text { of Helsinki, Journal of } \\
\text { Environmental Policy \& } \\
\text { Planning, } 2015 \text { Vol. 17, No. 5, } \\
\text { 538-552 }\end{array}$ & $\begin{array}{l}\text { local assessment and eventual remediation action. } \\
\text { Polluted soil as an environmental problem is examined in cases from three } \\
\text { different decades in Helsinki. The research material comprises official and } \\
\text { public documents, such as planning documents, records of the City Board and } \\
\text { interviews with the city's authorities. The analysis focuses on changes in } \\
\text { problem classification, knowledge production, risk management and the } \\
\text { dynamics between these. Risk management and knowledge production are } \\
\text { argued to have been conducted in a way that masks environmental problems, } \\
\text { their historical roots and their causes from citizens and decision-makers. } \\
\text { Furthermore, the risk management strategy transformed ecological risks into } \\
\text { financial risks. }\end{array}$ \\
\hline 11 & Alamdar et al. & 2014 & $\begin{array}{l}\text { Organochlorine pesticides in } \\
\text { surface soils from obsolete } \\
\text { pesticide dumping ground in } \\
\text { Hyderabad City, Pakistan: } \\
\text { Contamination levels and their } \\
\text { potential for air-soil } \\
\text { exchange, Science of the Total } \\
\text { Environment } 470-471 \text { (2014) } \\
733-741\end{array}$ & $\begin{array}{l}\text { This study was conducted to examine organochlorine pesticides (OCPs) } \\
\text { contamination levels in the surface soil and air samples together with air-soil } \\
\text { exchange fluxes at an obsolete pesticide dumping ground and the associated } \\
\text { areas from Hyderabad City, Pakistan. Elevated concentrations of DDTs and } \\
\text { HCHs at pesticide dumping ground and its surroundings pose potential } \\
\text { exposure risk to biological organisms, to the safety of agricultural products } \\
\text { and to the human health. The study thus emphasizes the need of spatio- } \\
\text { temporal monitoring of OCPs at local and regional scale to assess and } \\
\text { remediate the future adverse implications. }\end{array}$ \\
\hline 12 & G. Shi et al. & 2008 & $\begin{array}{l}\text { Potentially toxic metal } \\
\text { contamination of urban soils } \\
\text { and roadside dust in Shanghai, } \\
\text { China, Environmental } \\
\text { Pollution } 156 \text { (2008) 251-260 }\end{array}$ & $\begin{array}{l}\text { A detailed investigation was conducted to understand the contamination } \\
\text { characteristics of a selected set of potentially toxic metals in Shanghai. The } \\
\text { amount of } \mathrm{Pb}, \mathrm{Zn}, \mathrm{Cu}, \mathrm{Cr}, \mathrm{Cd} \text { and } \mathrm{Ni} \text { were determined from } 273 \text { soil/dust } \\
\text { samples collected within urban area. The results indicated that concentration } \\
\text { of all metals except } \mathrm{Ni} \text { in soils was significant, and metal pollution was even } \\
\text { severer in roadside dust. }\end{array}$ \\
\hline 13 & $\begin{array}{l}\text { Viacheslav } \\
\text { Vasenev, Yakov } \\
\text { Kuzyakov }\end{array}$ & 2018 & $\begin{array}{l}\text { Urban soils as hot spots of } \\
\text { anthropogenic carbon } \\
\text { accumulation: Review of } \\
\text { stocks, mechanisms and } \\
\text { driving factors, Land Degrad } \\
\text { Dev. 2018; 29: } 1607-1622\end{array}$ & $\begin{array}{l}\text { Data on soil organic carbon (SOC), soil inorganic carbon (SIC), black } \\
\text { (pyrogenic) carbon (BC), and nitrogen contents and stocks in urban soils were } \\
\text { collected from } 100 \text { peer - reviewed papers. Long - term C input from outside } \\
\text { the cities and associated C accumulation coincided with upward soil growth } \\
\text { of } ~ 50 \mathrm{~cm} \text { per century, and continuous accumulation of } 15-30 \mathrm{~kg} \text { C } / \mathrm{m} 2 \text { per } \\
\text { century in urban soils and cultural layers. Consequently, despite the relatively } \\
\text { small area of cities, urban soils are hot spots of long - term soil C } \\
\text { sequestration worldwide, and the importance of urban soils will increase in } \\
\text { future with global urbanization }\end{array}$ \\
\hline 14 & $\begin{array}{l}\text { Peter W. } \\
\text { Abrahams }\end{array}$ & 2006 & $\begin{array}{l}\text { Soil, geography and human } \\
\text { disease: a critical review of the } \\
\text { importance of medical } \\
\text { cartography, Progress in } \\
\text { Physical Geography } 30,4 \\
\text { (2006) pp. } 490-512\end{array}$ & $\begin{array}{l}\text { Soils have a profound impact on the causation and geographical distribution } \\
\text { of human disease and well-being.. Using examples, particularly the problems } \\
\text { of soil-transmitted helminth infections, and iodine and selenium deficiency } \\
\text { diseases, this paper shows how maps have been used to identify problem } \\
\text { areas, stimulate the development of aetiological hypotheses, help in the } \\
\text { planning and management of public health problems, and assess the impact of } \\
\text { any beneficial strategies. }\end{array}$ \\
\hline 15 & $\begin{array}{l}\text { E. C. Brevik and } \\
\text { T. J. Sauer }\end{array}$ & 2015 & $\begin{array}{l}\text { The past, present, and future of } \\
\text { soils and human health } \\
\text { studies, SOIL, 1, 35-46, 2015, } \\
\text { www.soil- } \\
\text { journal.net/1/35/2015 }\end{array}$ & $\begin{array}{l}\text { According to the present paper, complex interdisciplinary research teams are } \\
\text { needed with expertise in relevant areas and the ability for team members to } \\
\text { communicate effectively with one another at a professional level. Evidence } \\
\text { indicates that understanding the links between soils and human health should } \\
\text { be given more importance in human health research than it currently receives. }\end{array}$ \\
\hline
\end{tabular}

\subsection{Related Work for Health Effects and Risks of Human Exposure to Pollutants}

The majority of the articles referred to short or long term cohort studies [103, 149]. Others investigate the relation between exposure to pollutants (HMs, ECs, pesticides, insecticides, air pollutants) and elevated rate of chronic diseases such as cardiovascular, different types of cancers,

\section{Methodology \& Results}

Polluted soil as an environmental problem is examined in cases from three in interviews with the city's authorities. The analysis focuses on changes in problem classification, knowledge production, risk management and the mics between these. Risk management and knowledge production are their historical roots and their causes from citizens and decision-makers. Furthermore, the risk management strategy transformed ecological risks into cial risks. contamination levels in the surface soil and air samples together with air-soil exposure risk to biological organisms, to the safety of agricultural products characteristics of a selected set of potentially toxic metals in Shanghai. The amount of $\mathrm{Pb}, \mathrm{Zn}, \mathrm{Cu}, \mathrm{Cr}, \mathrm{Cd}$ and $\mathrm{Ni}$ were determined from 273 soil/dust severer in roadside dust. collected from 100 peer - reviewed papers. Long - term C input from outside the cities and associated $\mathrm{C}$ accumulation coincided with upward soil growth of $\sim 50 \mathrm{~cm}$ per century, and continuous accumulation of $15-30 \mathrm{~kg} \mathrm{C} / \mathrm{m} 2$ per in in the relatively of human disease and well-being.. Using examples, particularly the problems of soil-transmitted helminth infections, and iodine and selenium deficiency any beneficial strategies. be given more importance in human health research than it currently receives.

Table 4. Literature review of methods related health risks approximations due to pollution.

\begin{tabular}{lllll}
\hline a/a & Authors & Year & Title & Methodology \& Results \\
\hline & & $\begin{array}{l}\text { The role of pesticide } \\
\text { exposure in the genesis } \\
\text { of Parkinson's disease: }\end{array}$ & $\begin{array}{l}\text { The aim of this study was to address the uncertainties provided by epidemiological } \\
\text { studies on the role of pesticide exposures in the development of PD, with the help of } \\
\text { experimental toxicological data. Animal models that reproduce all clinical and } \\
\text { pathological features of human PD are not available. In addition, the fundamental } \\
\text { Epidemiological studies } \\
\text { and experimental data, } \\
\text { Toxicology } 307 \text { (2013) }\end{array}$ & $\begin{array}{l}\text { A. Moretto, C. } \\
\text { Colosions relate to the extrapolation from experimental to actual human exposure, taking } \\
\text { also into account the role of genetic factors. A possible role of acute poisonings or }\end{array}$ \\
\hline
\end{tabular}




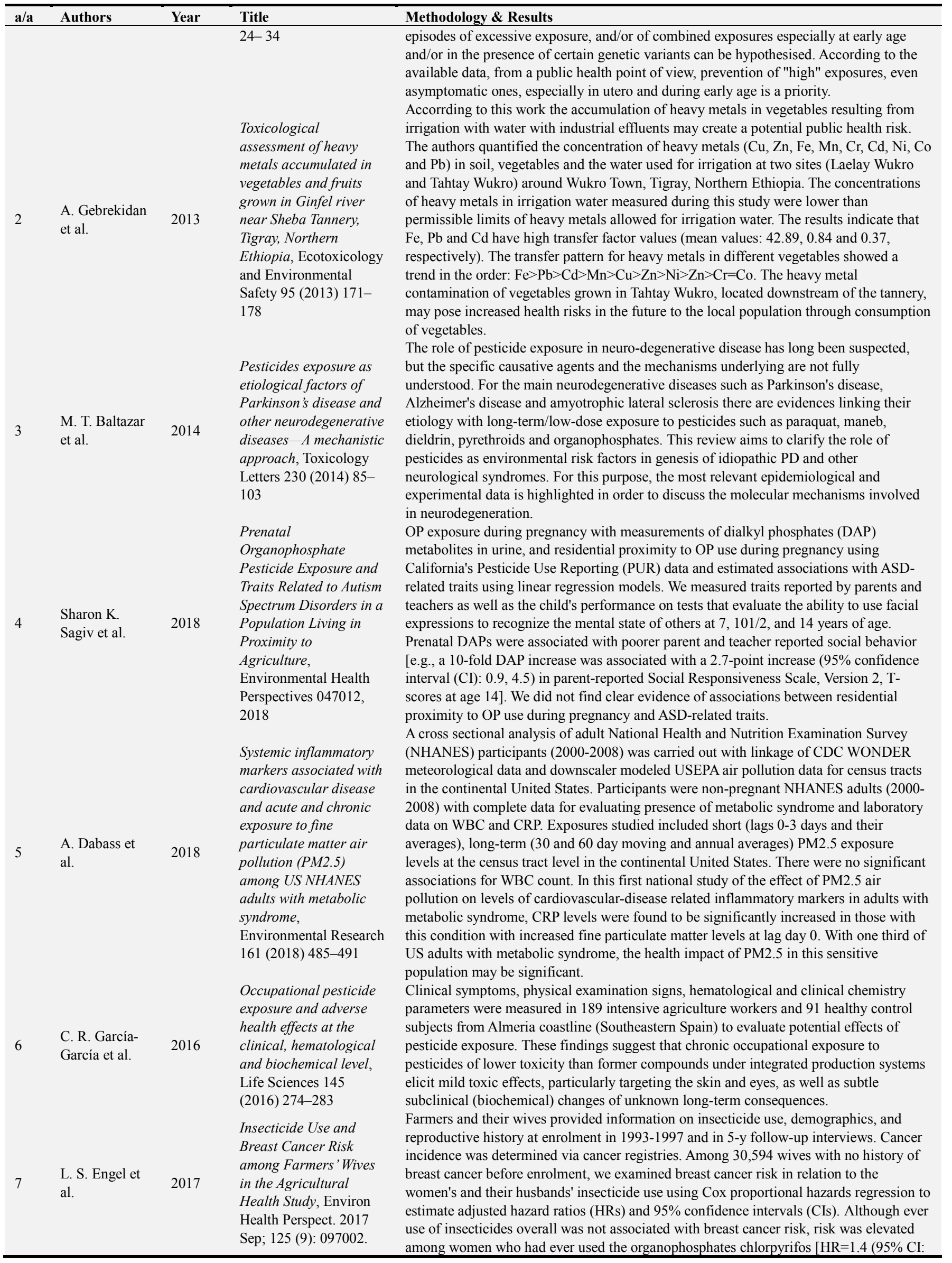




\begin{tabular}{|c|c|c|c|c|}
\hline $\mathbf{a} / \mathbf{a}$ & Authors & Year & Title & Methodology \& Results \\
\hline 8 & Louis et al. & 2017 & $\begin{array}{l}\text { A prospective study of } \\
\text { cancer risk among } \\
\text { Agricultural Health } \\
\text { Study farm spouses } \\
\text { associated with } \\
\text { personal use of } \\
\text { organochlorine } \\
\text { insecticides, } \\
\text { Environmental Health } \\
\text { (2017) 16: } 95\end{array}$ & 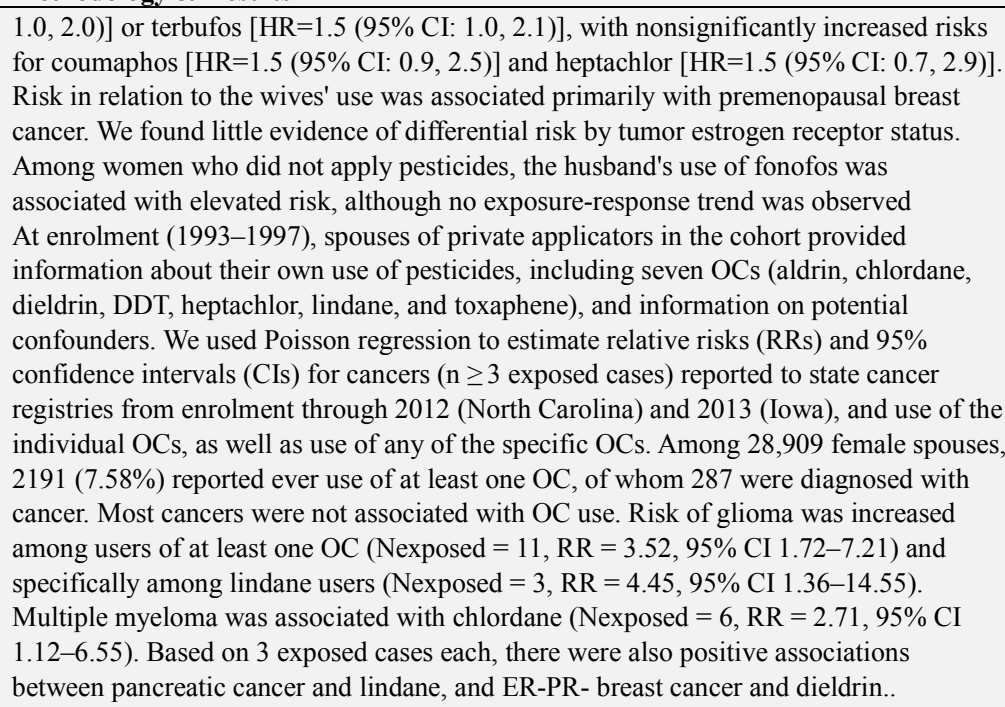 \\
\hline 9 & $\begin{array}{l}\text { Ming Ye, } \\
\text { Jeremy Beach, } \\
\text { Jonathan W. } \\
\text { Martin, } \\
\text { Ambikaipakan } \\
\text { Senthilselvan } \\
\text { X, }\end{array}$ & 2017 & $\begin{array}{l}\text { Pesticide exposures and } \\
\text { respiratory health in } \\
\text { general populations, } \\
\text { Journal of } \\
\text { Environmental Sciences } \\
51 \text { (2017) } 361-370\end{array}$ & $\begin{array}{l}\text { This article critically reviewed evidences up to date studying the associations between } \\
\text { non-occupational pesticide exposures and respiratory health in general populations. This } \\
\text { article also highlighted questions arising from these studies, including our recent } \\
\text { analyses using the data from the Canadian Health Measures Survey (CHMS), for future } \\
\text { research. We found few studies have addressed the impact of environmental pesticide } \\
\text { exposures on respiratory health, especially on lung function, in general populations. } \\
\text { Research findings from current studies of non-occupational pesticide exposures and their } \\
\text { health impact in general population will help to improve the role of regulatory policies in } \\
\text { mitigating pesticide-related public health problems, and thereafter providing greater } \\
\text { benefit to the general population. }\end{array}$ \\
\hline 10 & C. Piccoli et al. & 2016 & $\begin{array}{l}\text { Pesticide exposure and } \\
\text { thyroid function in an } \\
\text { agricultural population } \\
\text { in Brazil, Environmental } \\
\text { Research } 151 \text { (2016) } \\
\text { 389-398 }\end{array}$ & $\begin{array}{l}\text { A cross-sectional study was conducted with a random sample of } 275 \text { male and female } \\
\text { farm residents in Farroupilha, South of Brazil. Information on sociodemographics, } \\
\text { lifestyle and agricultural work was obtained through questionnaire. Blood samples were } \\
\text { collected on all participants and analyzed for cholinesterase activity, serum residues of } \\
\text { OC pesticides, and levels of free T4 (FT4), total T3 (TT3) and TSH. Non-persistent } \\
\text { pesticides exposure assessment was based on questionnaire information on current use of } \\
\text { pesticides, and frequency and duration of use, among others. Associations were explored } \\
\text { using multivariate linear regression models Subjects with detected serum concentrations } \\
\text { of } \beta \text {-hexachlorocyclohexane, endrin, dieldrin, heptachlor epoxide B, } \gamma \text {-chlordane, } \\
\text { transnonachlor, heptachlor, p, p'-dichlorodiphenylethane and endosulfan II experienced } \\
\text { slight changes in TT3; however, associations were weak and inconsistent. These findings } \\
\text { suggest that both cumulative and recent occupational exposure to agricultural pesticides } \\
\text { may affect the thyroid function causing hypothyroid-like effects, particularly in men. }\end{array}$ \\
\hline 11 & $\begin{array}{l}\text { J. F. Lebov et } \\
\text { al. }\end{array}$ & 2015 & $\begin{array}{l}\text { Pesticide exposure and } \\
\text { end-stage renal disease } \\
\text { risk among wives of } \\
\text { pesticide applicators in } \\
\text { the Agricultural Health } \\
\text { Study, Environmental } \\
\text { Research } 143 \text { (2015) } \\
\text { 198-210 }\end{array}$ & $\begin{array}{l}\text { AHS participants reported pesticide exposure via self-administered questionnaires at } \\
\text { enrollment (1993-1997). ESRD cases were identified via linkage to the United States } \\
\text { Renal Data System. Associations between ESRD and pesticide exposures were estimated } \\
\text { with Cox proportional hazard regression models controlling for age at enrollment. } \\
\text { Models of associations with farming and household factors were additionally adjusted for } \\
\text { personal use of pesticides. There were identified } 98 \text { ESRD cases diagnosed between } \\
\text { enrollment and } 31 \text { December 2011. Although women who ever applied pesticides ( } 56 \% \\
\text { of cohort) were less likely than those who did not apply to develop ESRD (Hazard Ratio } \\
\text { (HR): } 0.42 ; 95 \% \text { CI: } 0.28,0.64 \text { ), among women who did apply pesticides, the rate of } \\
\text { ESRD was significantly elevated among those who reported the highest (vs. lowest) } \\
\text { cumulative general pesticide use (HR: } 4.22 ; 95 \% \text { CI: } 1.26,14.20 \text { ). Among wives who } \\
\text { never applied pesticides, ESRD was associated with husbands' ever use of paraquat } \\
\text { (HR=1.99; } 95 \% \text { CI: } 1.14,3.47 \text { ) and butylate (HR }=1.71 ; 95 \% \text { CI: } 1.00,2.95 \text { ), with a } \\
\text { positive exposure-response pattern for husband's cumulative use of these pesticides }\end{array}$ \\
\hline 12 & $\begin{array}{l}\text { A. Gómez- } \\
\text { Martín et al. }\end{array}$ & 2015 & $\begin{array}{l}\text { Polymorphisms of } \\
\text { pesticide-metabolizing } \\
\text { genes in children living } \\
\text { in intensive farming } \\
\text { communities, } \\
\text { Chemosphere } 139 \\
\text { (2015) 534-540 }\end{array}$ & $\begin{array}{l}\text { This study explored the allelic frequency, linkage disequilibrium and haplotype analysis } \\
\text { of ten common polymorphic variants of seven key genes involved in organophosphate } \\
\text { metabolismin a children population living near an intensive agriculture area in Spain. It } \\
\text { was hypothesized that individuals with unfavorable combinations of gene variants will be } \\
\text { more susceptible to adverse effects from organophosphate exposure. Genomic DNA from } \\
496 \text { healthy children was isolated and amplified by PCR. Hydrolysis probes were used } \\
\text { for the detection of eight specific SNPs and two copy number variants (CNVs) by using } \\
\text { TaqMan® Assay-based real-time PCR. The adverse genotype combination potentially } \\
\text { conferring a greater genetic risk from exposure to organophosphates was observed in } \\
0.2 \% \text { of our study population. This information allows broadening our knowledge about }\end{array}$ \\
\hline
\end{tabular}




\begin{tabular}{|c|c|c|c|}
\hline $\mathbf{a} / \mathbf{a}$ & Authors & Year & Title \\
\hline 13 & $\begin{array}{l}\text { X Rupali Das, } \\
\text { Andrea Steege, } \\
\text { Sherry Baron, } \\
\text { John Beckman } \\
\text { \& Robert } \\
\text { Harrison }\end{array}$ & 2001 & $\begin{array}{l}\text { Pesticide-related Illness } \\
\text { among Migrant Farm } \\
\text { Workers in the United } \\
\text { States, Journal of } \\
\text { Occupational and } \\
\text { Environmental Health, } \\
\text { 7: 4, 303-312 }\end{array}$ \\
\hline
\end{tabular}

S. Mostafalou, M. Abdollahi chronic diseases: Evidences, mechanisms, and perspectives, Toxicology and Applied Pharmacology 268

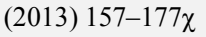

Farmyards, an overlooked source for highly contaminated A. C. Edwards $2008 \quad$ runoff, Journal of et al. Environmental Management 87 (2008) 551-559

\section{Methodology \& Results}

differential susceptibility toward environmental toxicants and may be helpful for further research to understand the inter-individual toxicokinetic variability in response to organophosphate pesticides exposure.

A few categories (organophosphates and carbamates, inorganic compounds, and pyrethroids) account for over half of the cases of acute illness. Skin effects dominate the illnesses, although ocular and systemic effects are also common. Exposures occur in various ways (e.g., residues, drift), suggesting that the use of pesticides creates a hazardous work environment for all farm workers. The health care system provided through the Migrant Health Program appears to be underutilized, partially due to barriers to health care access. Current surveillance effort should be supported. Risk prevention should focus on substitution of safer compounds, establishing effective protections, and ensuring that these measures are enforced. Improved education for health care providers should be a priority. Growers should be educated about alternative forms of pest control and incentives should be provided to encourage their use.

According to existed literature there is a huge body of evidence on the relation between exposure to pesticides and elevated rate of chronic diseases such as different types of cancers, diabetes, neurodegenerative disorders like Parkinson, Alzheimer, and amyotrophic lateral sclerosis (ALS), birth defects, and reproductive disorders. There is also circumstantial evidence on the association of exposure to pesticides with some other chronic diseases like respiratory problems, particularly asthma and chronic obstructive pulmonary disease (COPD), cardiovascular disease such as atherosclerosis and coronary artery disease, chronic nephropathies, autoimmune diseases like systemic lupus erythematous and rheumatoid arthritis, chronic fatigue syndrome, and aging. Authors in this review, present the highlighted evidence on the association of pesticide's exposure with the incidence of chronic diseases and introduce genetic damages, epigenetic modifications, endocrine disruption, mitochondrial dysfunction, oxidative stress, endoplasmic reticulum stress and unfolded protein response (UPR), impairment of ubiquitin proteasome system, and defective autophagy as the effective mechanisms of action.

In this study the separate analysis of roof runoff indicated that these can contribute significant concentrations of FS, phosphorus (P) and potentially toxic elements such as zinc $(\mathrm{Zn})$, and suggests a level of 'background' contamination originating from wash-off of bird droppings and in the case of $\mathrm{Zn}$ galvanised surfaces. On average hardstanding runoff showed enhanced concentrations of $>4$ orders of magnitude for FC and 2-3 for major nutrients and carbon relative to roof runoff. Where situations allowed, a comparison of water upstream and downstream of the farmyard demonstrated they acted as a source of multiple contaminants not only during hydrologically active storm events but also during dry periods. Contamination pathways included a combination of both point (e.g., septic overflows) and non-point (e.g., seepage from livestock housing) sources. Farmyards situated within intensive livestock farming areas such as SW Scotland, would be expected to have significant local and accumulated downstream impacts on the aquatic environment. Localised impacts would be particularly important for headwaters and low order streams

This study looks at all airports of Texas, and 2134 incidences of childhood leukemia (children age 9 and under) state-wide over a 10-year period. The distance to airports of block groups with standardized incidence ratios $>100$ for childhood leukemia was found to be shorter than the distance to airports for block groups with standardized incidence ratios $<100$, to a $98 \%$ level of confidence. A Poisson regression model was developed to estimate incidences of childhood leukemia, based on county-wide benzene emissions. Benzene emissions from airports were found to be a statistically significant predictor variable. The two analyses provide evidence of an association between airports and incidences of childhood leukemia in Texas

Clinical symptoms, physical examination signs, hematological and clinical chemistry parameters were measured in 189 intensive agriculture workers and 91 healthy control subjects from Almeria coastline (Southeastern Spain) to evaluate potential effects of pesticide exposure. According to the present study chronic occupational exposure to pesticides of lower toxicity than former compounds under integrated production systems elicit mild toxic effects, particularly targeting the skin and eyes, as well as subtle subclinical (biochemical) changes of unknown long-term consequences Conducted a study of women enrolled in the Western New York Exposures and Breast Cancer (WEB) Study. Methylation of nine genes, was assessed using bisulfite-based pyrosequencing. TSP exposure at each woman's home address at birth, menarche, and when she had her first child was estimated. TE exposure was modeled for each woman's residence at menarche, her first birth, and twenty and ten years prior to diagnosis. Unconditional logistic regression was employed to estimate odds ratios (OR) of having methylation greater than the median value, adjusting for age, secondhand smoke exposure before age 20 , current smoking status, and estrogen receptor status. It was 


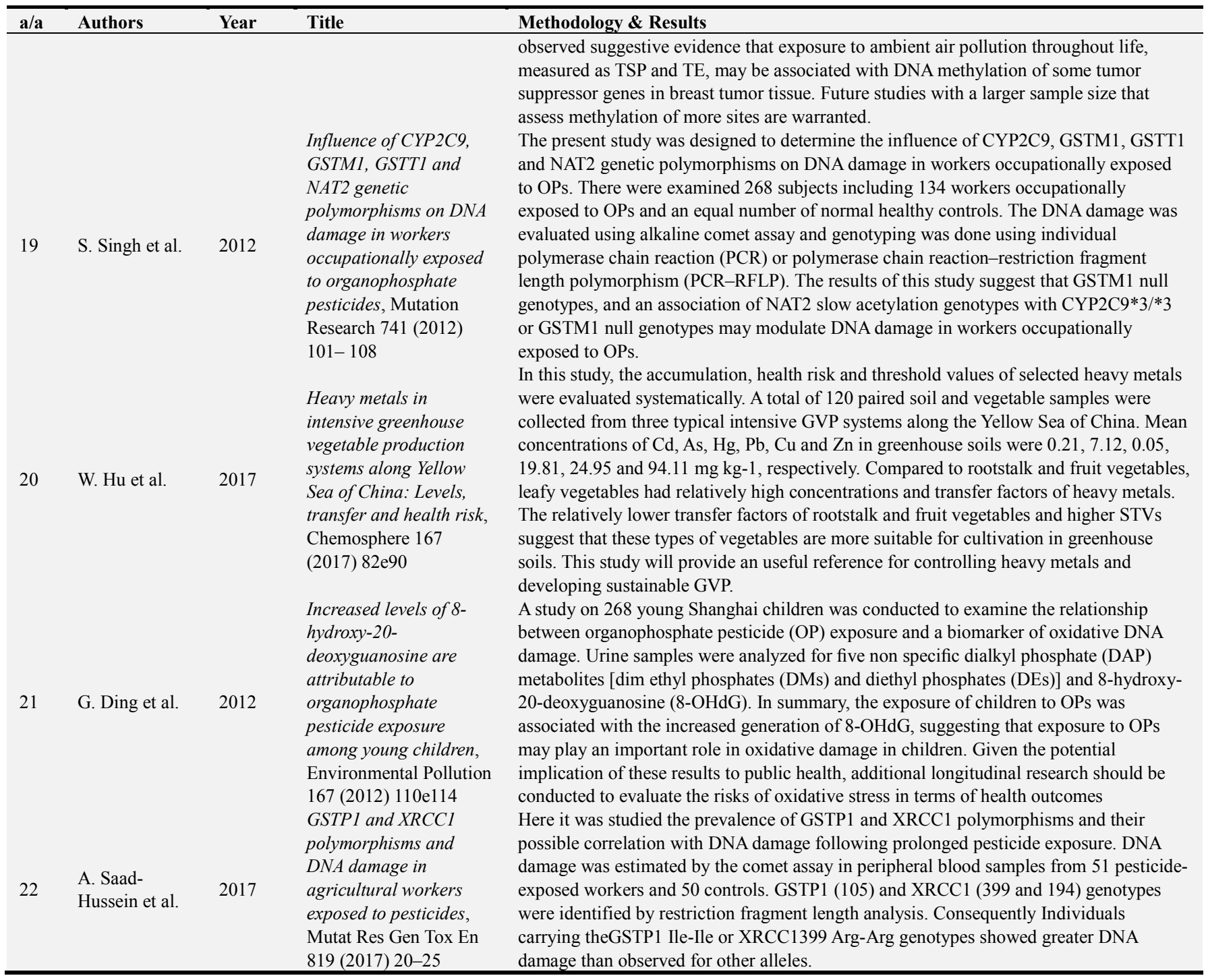

\subsection{Related Work for Environmental Centers}

There are studies, as is presented in Table 5 that referred to environmental centers where measuring and monitoring key environmental variables and in collaboration with authorities supervise compliance with provisions and regulations [117-126, 128-139].

Table 5. Literature review of methods related to established environmental centers.

\begin{tabular}{|c|c|c|c|c|}
\hline $\mathbf{a} / \mathbf{a}$ & Authors & Year & Title & Methodology \& Results \\
\hline 1 & $\begin{array}{l}\text { M. S. El- } \\
\text { Shahawi et al. }\end{array}$ & 2010 & $\begin{array}{l}\text { An overview on the } \\
\text { accumulation, distribution, } \\
\text { transformations, toxicity and } \\
\text { analytical methods for the } \\
\text { monitoring of persistent } \\
\text { organic pollutants, Talanta } 80 \\
\text { (2010) 1587-1597. }\end{array}$ & $\begin{array}{l}\text { In this important approach a comprehensive review with } 108 \text { references referring } \\
\text { to the distribution, source, accumulation, transformation, types and toxicity of } \\
\text { polychlorinated biphenyls (PCBs) and organochlorine pesticides (OCPs) is } \\
\text { presented. The review also aimed to highlight on the current best practices for the } \\
\text { analysis of PCBs and OCPs with the signing of the Stockholm convention on } \\
\text { POPs and the development of global monitoring programs, there is an increased } \\
\text { need for laboratories in developing countries to determine such class of chemicals. } \\
\text { A major focus revealed the need for low cost methods that can be implemented } \\
\text { easily in developing countries such as electrochemical techniques. }\end{array}$ \\
\hline 2 & $\begin{array}{l}\text { Ramasamy } \\
\text { Rajamanickam } \\
\text {, S. Nagan, }\end{array}$ & 2018 & $\begin{array}{l}\text { Assessment of Comprehensive } \\
\text { Environmental Pollution Index } \\
\text { of Kurichi Industrial Cluster, } \\
\text { Coimbatore District, Tamil } \\
\text { Nadu, India - a Case Study, } \\
\text { Journal of Ecological } \\
\text { Engineering Volume 19, Issue } \\
\text { 1, January 2018, pages 191- }\end{array}$ & $\begin{array}{l}\text { In India the Central Pollution Control Board (CPCB) has brought out revised } \\
\text { criteria for evaluation of CEPI by replacing the criteria issued in } 2010 \text {. According } \\
\text { to the present study the CEPI score is below } 70 \text { which imply that the industrial } \\
\text { units are operating and maintaining the pollution control measures consistently. } \\
\text { However, taking a policy decision based on the CEPI score, researchers should be } \\
\text { cautious on the adequacy of data and the parameters selected. }\end{array}$ \\
\hline
\end{tabular}




\begin{tabular}{|c|c|c|c|c|}
\hline $\mathbf{a} / \mathbf{a}$ & Authors & Year & Title & Methodology \& Results \\
\hline & & & 199 & \\
\hline 3 & $\begin{array}{l}\text { J. S. } \\
\text { Horsburgh et } \\
\text { al., }\end{array}$ & 2011 & $\begin{array}{l}\text { Components of an } \\
\text { environmental observatory } \\
\text { information system, Computers } \\
\text { \& Geosciences } 37 \text { (2011) 207- } \\
218\end{array}$ & $\begin{array}{l}\text { In this paper, is in details described the architecture and functional requirements } \\
\text { for an environmental observatory information system that supports collection, } \\
\text { organization, storage, analysis, and publication of hydrologic observations. The } \\
\text { components demonstrated comprise an observatory information system that } \\
\text { enables not only the management, analysis, and synthesis of environmental } \\
\text { observations data for a single observatory, but also publication of the data on the } \\
\text { Internet in simple to use formats that are easily accessible, discoverable by others, } \\
\text { and interoperable with data from other observatories. }\end{array}$ \\
\hline 4 & Keller et al., & 2015 & $\begin{array}{l}\text { A Unified Spatiotemporal } \\
\text { Modeling Approach for } \\
\text { Predicting Concentrations of } \\
\text { Multiple Air Pollutants in the } \\
\text { Multi-Ethnic Study of } \\
\text { Atherosclerosis and Air } \\
\text { Pollution, Environmental } \\
\text { Health Perspectives • volume } \\
123 \text { | number } 4 \mid \text { April } 2015\end{array}$ & $\begin{array}{l}\text { According to the present study, monitoring data obtained from regulatory } \\
\text { networks and supplemented those data with study-specific measurements collected } \\
\text { from MESA Air community locations and participants' homes. In each region, we } \\
\text { applied a spatiotemporal model that included a long-term spatial mean, time trends } \\
\text { with spatially varying coefficients, and a spatiotemporal residual. The mean } \\
\text { structure was derived from a large set of geographic covariates that was reduced } \\
\text { using partial least-squares regression. This novel spatiotemporal modeling } \\
\text { approach provides accurate fine-scale predictions in multiple regions for four } \\
\text { pollutants. There have been generated participant-specific predictions for MESA } \\
\text { Air to investigate health effects of long-term air pollution exposures. These } \\
\text { successes highlight modeling advances that can be adopted more widely in } \\
\text { modern cohort studies. }\end{array}$ \\
\hline 5 & Kumar et al.,. & 2015 & $\begin{array}{l}\text { The rise of low-cost sensing for } \\
\text { managing air pollution in } \\
\text { cities, Environment } \\
\text { International } 75,2015,199- \\
205\end{array}$ & $\begin{array}{l}\text { Conventional approaches to air quality monitoring are based on networks of static } \\
\text { and sparse measurement stations. However, these are prohibitively expensive to } \\
\text { capture tempo-spatial heterogeneity and identify pollution hotspots, which is } \\
\text { required for the development of robust real-time strategies for exposure control. } \\
\text { This study illustrates the drivers behind current rises in the use of low-cost sensors } \\
\text { for air pollution management in cities, while addressing the major challenges for } \\
\text { their effective implementation }\end{array}$ \\
\hline 6 & G. Hoek et al., & 2008 & $\begin{array}{l}\text { A review of land-use regression } \\
\text { models to assess spatial } \\
\text { variation of outdoor air } \\
\text { pollution, Atmospheric } \\
\text { Environment } 42 \text { (2008) 7561- } \\
7578\end{array}$ & $\begin{array}{l}\text { This paper provided a critical review of the different components of LUR models. } \\
\text { There were identified } 25 \text { land-use regression studies. Land-use regression } \\
\text { combines monitoring of air pollution at typically } 20-100 \text { locations, spread over the } \\
\text { study area, and development of stochastic models using predictor varModels that } \\
\text { include a spatial and a temporal component are of interest for (e.g. birth cohort) } \\
\text { studies that need exposure variables on a finer temporal scale. Finally, there is a } \\
\text { strong need for validation of LUR models with personal exposure monitoring. }\end{array}$ \\
\hline 7 & $\begin{array}{l}\text { Ozgur Kisi, } \\
\text { Kulwinder } \\
\text { Singh Parmar, }\end{array}$ & 2016 & $\begin{array}{l}\text { Application of least square } \\
\text { support vector machine and } \\
\text { multivariate adaptive } \\
\text { regression spline models in } \\
\text { long term prediction of river } \\
\text { water pollution, Journal of } \\
\text { Hydrology Volume 534, March } \\
2016 \text {, Pages 104-112 }\end{array}$ & $\begin{array}{l}\text { This study investigated the accuracy of least square support vector machine } \\
\text { (LSSVM), multivariate adaptive regression splines (MARS) and M5 model tree } \\
\text { (M5Tree) in modeling river water pollution. Various combinations of water quality } \\
\text { parameters, Free Ammonia (AMM), Total Kjeldahl Nitrogen (TKN), Water } \\
\text { Temperature (WT), Total Coliform (TC), Fecal Coliform (FC) and Potential of } \\
\text { Hydrogen (pH) monitored at Nizamuddin, Delhi Yamuna River in India were used } \\
\text { as inputs to the applied models. Results indicated that the LSSVM and MARS } \\
\text { models had almost same accuracy and they performed better than the M5Tree } \\
\text { model in modeling monthly chemical oxygen demand (COD). The overall results } \\
\text { indicated that the MARS and LSSVM models could be successfully used in } \\
\text { estimating monthly river water pollution level by using AMM, TKN and WT } \\
\text { parameters as inputs. }\end{array}$ \\
\hline 8 & $\begin{array}{l}\text { G. } \\
\text { Prud'homme et } \\
\text { al., }\end{array}$ & 2013 & $\begin{array}{l}\text { Comparison of remote sensing } \\
\text { and fixed-site monitoring } \\
\text { approaches for examining air } \\
\text { pollution and health in a } \\
\text { national study population, } \\
\text { Atmospheric Environment } 80 \\
\text { (2013) } 161 \mathrm{e} 171\end{array}$ & $\begin{array}{l}\text { In this study there were examined associations between air pollution and adverse } \\
\text { respiratory and allergic health outcomes using multi-year averages of NO2 and } \\
\text { PM2.5 from RS and from regulatory monitoring. RS estimates were derived using } \\
\text { satellite measurements from OMI, MODIS, and MISR instruments. Regulatory } \\
\text { monitoring data were obtained from Canada's National Air Pollution Surveillance } \\
\text { Network. The consistency between risk estimates based on RS and regulatory } \\
\text { monitoring as well as the associations between air pollution and health among } \\
\text { participants living outside the catchment area for regulatory monitoring suggest } \\
\text { that RS can provide useful estimates of long-term ambient air pollution in } \\
\text { epidemiologic studies. This is particularly important in rural communities and } \\
\text { other areas where monitoring and modeled air pollution data are limited or } \\
\text { unavailable }\end{array}$ \\
\hline 9 & $\begin{array}{l}\text { Tamás Fráter } \\
\text { et al., }\end{array}$ & 2015 & $\begin{array}{l}\text { Unmanned Aerial Vehicles in } \\
\text { Environmental Monitoring-An } \\
\text { Efficient Way for Remote } \\
\text { Sensing, Journal of } \\
\text { Environmental Science and } \\
\text { Engineering A } 4 \text { (2015) 85-91 }\end{array}$ & $\begin{array}{l}\text { In this recent experimental work, aerial photos were made in Bakony Mountains } \\
\text { using three UAVs equipped with small HD (high definition) cameras; resolution: } \\
1,280 \times 720 \text { pixels. The airborne surveillance of areas of ragweed (Ambrosia sp.) } \\
\text { populations was also investigated. It was found that both UAVs are feasible for } \\
\text { these tasks, and the application of these platforms for environmental monitoring is } \\
\text { advantageous, especially in case of natural reserve areas since those are very silent } \\
\text { and (contrary to big aircrafts and helicopters) do not disturb the ecology even in } \\
\text { natural reserve areas and the people living there. Moreover, those could be }\end{array}$ \\
\hline
\end{tabular}




\begin{tabular}{|c|c|c|c|c|}
\hline $\mathbf{a} / \mathbf{a}$ & Authors & Year & Title & Methodology \& Results \\
\hline & & & & $\begin{array}{l}\text { operated in a very flexible and economic way, and the aerial photos taken are } \\
\text { highly informative }\end{array}$ \\
\hline 10 & $\begin{array}{l}\text { Ozgur Kisi, } \\
\text { Kulwinder } \\
\text { Singh Parmar, } \\
\text { Kirti Soni, } \\
\text { Vahdettin } \\
\text { Demir, }\end{array}$ & 2017 & $\begin{array}{l}\text { Modeling of air pollutants } \\
\text { using least square support } \\
\text { vector regression, multivariate } \\
\text { adaptive regression spline, and } \\
\text { M5 model tree models, Air } \\
\text { Quality, Atmosphere \& Health } \\
\text { September 2017, Volume } 10, \\
\text { Issue } 7, \text { pp } 873-883\end{array}$ & $\begin{array}{l}\text { This study investigated the applicability of three different soft computing methods, } \\
\text { least square support vector regression (LSSVR), multivariate adaptive regression } \\
\text { splines (MARS), and M5 Model Tree (M5-Tree), in forecasting } \mathrm{SO}_{2} \text { concentration. } \\
\text { According to the comparison, LSSVR provided better accuracy than the other } \\
\text { models, while the MARS model was found to be the second best model in } \\
\text { forecasting monthly } \mathrm{SO}_{2} \text { concentration. Results indicated that the applied models } \\
\text { gave better forecasting accuracy in Janakpuri station than the other stations. The } \\
\text { results were also compared with previous studies and satisfactory results were } \\
\text { obtained from three methods in modeling SO2 concentrations }\end{array}$ \\
\hline 11 & $\begin{array}{l}\text { Arshia } \\
\text { Chander et al., }\end{array}$ & 2013 & $\begin{array}{l}\text { A new eye in the sky: Eco- } \\
\text { drones, Environmental } \\
\text { Development Volume } 7 \text {, July } \\
\text { 2013, Pages 155-164 }\end{array}$ & $\begin{array}{l}\text { According to the present study, lightweight and easy to transport. low-cost high } \\
\text { resolution images Low-cost operations can fly at variety of altitudes depending on } \\
\text { data collection needs can map areas not accessible by car, boat, etc. on an on- } \\
\text { demand time schedule. Video recording capabilities. Quick availability of raw } \\
\text { data. Limited flight time depending on model. Limited by camera weight. Air } \\
\text { space limitations and restrictions can be limited by wind speed and gusts. Limited } \\
\text { amount of appropriate software. Time intensive to create orthomosaics with } \\
\text { minimal geographic reference errors. Due to small image footprint, numerous } \\
\text { images must be captured }\end{array}$ \\
\hline 12 & $\begin{array}{l}\text { G. Di Stefano } \\
\text { et al., }\end{array}$ & 2018 & $\begin{array}{l}\text { The Lusi drone: A multi- } \\
\text { disciplinary tool to access } \\
\text { extreme environments, Marine } \\
\text { and Petroleum Geology } 90 \\
\text { (2018) 26e } 37\end{array}$ & $\begin{array}{l}\text { A multipurpose drone has been designed and constructed to access and sample } \\
\text { extreme environments. Gas, water, and mud sampling is coupled with temperature } \\
\text { measurements, video records, photogrammetry, infra-red, and gas distribution } \\
\text { mapping. Successful missions have been completed at the active Lusi eruption } \\
\text { site. The drone is an excellent tool to study harsh or unreachable sites where } \\
\text { conventional operations are too expensive, dangerous or impossible. }\end{array}$ \\
\hline 14 & $\begin{array}{l}\text { José I. Suárez } \\
\text { et al., }\end{array}$ & 2018 & $\begin{array}{l}\text { Bluetooth Electronic Nose for } \\
\text { Odour Monitoring and Control, } \\
\text { Chemical Engineering } \\
\text { transactions, Vol. } 68,2018\end{array}$ & $\begin{array}{l}\text { A novel miniaturized prototype of an electronic nose, which includes commercial } \\
\text { MEMS gas sensors for odour recognition, has been presented. It also includes a } \\
\text { temperature and humidity sensor, which is often omitted in the design of many } \\
\text { electronic noses. The use of a Bluetooth module enables the e-nose } \\
\text { communications with a smartphone, where data are transmitted on-the-fly and } \\
\text { stored for later processing. The results from the application of the leave-one-out } \\
\text { cross-validation technique show that the systems has a very high success rate } \\
\text { (close to } 98 \% \text { ) in the pollutant discrimination at different gas concentration. }\end{array}$ \\
\hline 15 & $\begin{array}{l}\text { N. Castell et } \\
\text { al., }\end{array}$ & 2017 & $\begin{array}{l}\text { Can commercial low-cost } \\
\text { sensor platforms contribute to } \\
\text { air quality monitoring and } \\
\text { exposure estimates?, } \\
\text { Environment International } 99 \\
\text { (2017) 293-302 }\end{array}$ & $\begin{array}{l}\text { An exhaustive evaluation of } 24 \text { identical units of a commercial low-cost sensor } \\
\text { platform against CEN (European Standardization Organization) reference } \\
\text { analysers, evaluating their measurement capability over time and a range of } \\
\text { environmental conditions. Results show that their performance varies spatially and } \\
\text { temporally, as it depends on the atmospheric composition and the meteorological } \\
\text { conditions. }\end{array}$ \\
\hline 16 & $\begin{array}{l}\text { A. Moreno- } \\
\text { Rangel et al., }\end{array}$ & 2018 & $\begin{array}{l}\text { Field evaluation of a low-cost } \\
\text { indoor air quality monitor to } \\
\text { quantify exposure to pollutants } \\
\text { in residential environments, } \\
\text { Journal of Sensors Sensor } \\
\text { Systems, 7, 373-388, } 2018\end{array}$ & $\begin{array}{l}\text { This paper presents a user study to assess the precision, accuracy, and usability of } \\
\text { a low-cost indoor air quality monitor in a residential environment to collect data } \\
\text { about the indoor pollution. The findings suggest that Foobot is sufficiently } \\
\text { accurate for identifying high pollutant exposures with potential health risks and for } \\
\text { providing data at high granularity and good potential for user or scientific } \\
\text { applications due to remote data retrieval. It may also be well suited to remote and } \\
\text { larger-scale studies in quantifying exposure to pollutants. }\end{array}$ \\
\hline 17 & $\begin{array}{l}\text { World } \\
\text { Meteorological } \\
\text { Organization } \\
\text { (WMO) }\end{array}$ & 2018 & $\begin{array}{l}\text { Low-cost sensors for the } \\
\text { measurement of atmospheric } \\
\text { composition: overview of topic } \\
\text { and future applications, World } \\
\text { Meteorological Organization } \\
\text { (WMO) }\end{array}$ & $\begin{array}{l}\text { This report considers sensors that are designed for the measurement of } \\
\text { atmospheric composition at ambient concentrations focusing on reactive gaseous } \\
\text { air pollutants }(\mathrm{CO}, \mathrm{NOx}, \mathrm{O} 3, \mathrm{SO} 2) \text {, particulate matter (PM) and greenhouse gases } \\
\mathrm{CO} 2 \text { and } \mathrm{CH} 4 \text {. Smaller and/or lower cost devices tend to be less sensitive, less } \\
\text { precise and less chemically-specific to the compound or variable of interest. This } \\
\text { is balanced by a potential increase in the spatial density of measurements that can } \\
\text { be achieved by a network of sensors. }\end{array}$ \\
\hline 18 & $\begin{array}{l}\text { Stanislaw } \\
\text { Anweiler, } \\
\text { Dawid } \\
\text { Piwowarski }\end{array}$ & 2017 & $\begin{array}{l}\text { Multicopter platform prototype } \\
\text { for environmental monitoring, } \\
\text { Journal of Cleaner Production } \\
\text { Volume } 155 \text {, Part } 1 \text {, } 1 \text { July } \\
2017 \text {, Pages 204-211 }\end{array}$ & $\begin{array}{l}\text { In this application a multirotor concept was created, which assumed some } \\
\text { executive functions i.e. hovering, environmental data acquisition or Global } \\
\text { Positioning System movement. On the basis of these assumptions, platform } \\
\text { components were chosen. They included: the frame, drives, electronics and } \\
\text { software. A platform that is able to accomplish the tasks was created. All } \\
\text { components of the multicopter have been described, materials used, mounting and } \\
\text { connecting them, as well as the presentation of the specific device problems. } \\
\text { Scientific value of the paper includes the guidance of cheap and efficient setup } \\
\text { along with the applications. }\end{array}$ \\
\hline 19 & Dieter Schwela & 2012 & $\begin{array}{l}\text { Review of Urban Air Quality in } \\
\text { Sub-Saharan Africa Region - } \\
\text { Air Quality profile of SSA } \\
\text { countries, Washington, DC: }\end{array}$ & $\begin{array}{l}\text { This work presents methods for water quality monitoring (WQM) from traditional } \\
\text { manual methods to more technologically advanced methods employing wireless } \\
\text { sensor networks (WSNs) for in situ WQM. The safety of the data and the entire } \\
\text { network in the WQM process is paramount. Issues with malicious attackers or }\end{array}$ \\
\hline
\end{tabular}




\begin{tabular}{|c|c|c|c|c|}
\hline $\mathbf{a} / \mathbf{a}$ & Authors & Year & Title & Methodology \& Results \\
\hline & & & World Bank & $\begin{array}{l}\text { physical breakdown of the infrastructure, eavesdropping, and traffic analysis } \\
\text { should be thoroughly considered in future systems. Data processing and } \\
\text { aggregation algorithms should be developed to ensure proper data management, } \\
\text { and biofouling, sensor drift, and underwater communication are all issues that } \\
\text { should be considered in the development of WSNs for WQM. }\end{array}$ \\
\hline 20 & $\begin{array}{l}\text { Prashant } \\
\text { Kumar et al. }\end{array}$ & 2015 & $\begin{array}{l}\text { The rise of low-cost sensing for } \\
\text { managing air pollution in } \\
\text { cities, Environment } \\
\text { International } 2015 \mathrm{Feb} ; 75 \text { : } \\
\text { 199-205 }\end{array}$ & $\begin{array}{l}\text { Conventional approaches to air quality monitoring are based on networks of static } \\
\text { and sparse measurement stations. Current progress in developing low-cost micro- } \\
\text { scale sensing technology is radically changing the conventional approach to allow } \\
\text { real-time information in a capillary form. But the question remains whether there } \\
\text { is value in the less accurate data they generate. }\end{array}$ \\
\hline 21 & $\begin{array}{l}\text { K. S. Adu- } \\
\text { Manu et al. }\end{array}$ & 2016 & $\begin{array}{l}\text { Water Quality Monitoring } \\
\text { Using Wireless Sensor } \\
\text { Networks: Current Trends and } \\
\text { Future Research Directions, } \\
\text { Trans. Sensor Netw. 00, 00, } \\
\text { Article } 000 \text { ( } 2016\end{array}$ & $\begin{array}{l}\text { In this work, were reviewed methods for water quality monitoring (WQM) from } \\
\text { traditional manual methods to more technologically advanced methods employing } \\
\text { wireless sensor networks (WSNs) for in situ WQM. In particular, it was } \\
\text { highlighted recent developments in the sensor devices, data acquisition } \\
\text { procedures, communication and network architectures, and power management } \\
\text { schemes to maintain a long-lived operational WQM system. Finally, according the } \\
\text { discussion additional open issues need to be addressed to further advance } \\
\text { automatic WQM using WSNs. }\end{array}$ \\
\hline 22 & M. Pule et al. & 2017 & $\begin{array}{l}\text { Wireless sensor networks: A } \\
\text { survey on monito-ring water } \\
\text { quality, Journal of Applied } \\
\text { Research and Technology } 15, \\
\text { Issue } 6 \text { (2017) 562-57 }\end{array}$ & $\begin{array}{l}\text { This work surveys the application of WSN in environmental monitoring, with } \\
\text { particular emphasis on water quality. }\end{array}$ \\
\hline 23 & $\begin{array}{l}\text { Christopher J. } \\
\text { Paciorek and } \\
\text { Yang Liu }\end{array}$ & 2012 & $\begin{array}{l}\text { Assessment and Statistical } \\
\text { Modeling of the Relationship } \\
\text { Between Remotely Sensed } \\
\text { Aerosol Optical Depth and } \\
\text { PM2.5 in the Eastern United } \\
\text { States, } 2012 \text { HEI Research } \\
\text { Report } 167\end{array}$ & $\begin{array}{l}\text { In this study there were developed specific statistical models for integrating } \\
\text { monitoring, satellite, and geographic information system (GIS) data to estimate } \\
\text { monthly ambient PM } 2.5 \text { concentrations and used those models to estimate } \\
\text { monthly average PM2.5 concentrations across the eastern United States. Authors } \\
\text { finally developed and applied statistical methods to quantify how uncertainties in } \\
\text { exposure estimates based on ground-level monitoring data might be reduced. }\end{array}$ \\
\hline
\end{tabular}

\subsection{Related Work for Ionizing or Non-ionizing Radiation}

Many methods in the reviewed studies refer to monitoring the possible human health effects of electromagnetic fields [142, 143], or microwave radiation [144], as is presented in Table 6.

Table 6. Literature review of methods related to radiation.

\begin{tabular}{|c|c|c|c|c|}
\hline $\mathbf{a} / \mathbf{a}$ & Authors & Year & Title & Methodology \& Results \\
\hline 1 & I Maccà et al. & 2008 & $\begin{array}{l}\text { Occupational exposure to } \\
\text { electromagnetic fields in } \\
\text { physiotherapy departments. } \\
\text { Radiation protection dosimetry, } 128 \\
\text { (2), } 180-190\end{array}$ & $\begin{array}{l}\text { In this work in order to assess occupational exposure to electromagnetic } \\
\text { fields, } 11 \text { microwave (MW), } 4 \text { short-wave diathermy and } 15 \text { magneto } \\
\text { therapy devices were analysed in eight physiotherapy departments. Results } \\
\text { reveal that although most areas show substantially low levels of } \\
\text { occupational exposure to electromagnetic fields in physiotherapy units, } \\
\text { certain cases of over-occupational exposure limits do exist }\end{array}$ \\
\hline 2 & $\begin{array}{l}\text { Gryz K. } \\
\text { Zradziński, P. \& } \\
\text { Karpowicz J. }\end{array}$ & 2015 & $\begin{array}{l}\text { The role of the location of personal } \\
\text { exposimeters on the human body in } \\
\text { their use for assessing exposure to } \\
\text { the electromagnetic field in the } \\
\text { radiofrequency range } 98-2450 \\
\text { MHz and compliance analysis: } \\
\text { evaluation by virtual measurements. } \\
\text { BioMed research international, } \\
2015 \text {. }\end{array}$ & $\begin{array}{l}\text { Calculations with } 256 \text { models of exposure scenarios show that the human } \\
\text { body has a significant influence on the results of measurements using a } \\
\text { single body-worn exposimeter in various locations near the body ((from }-96 \\
\text { to }+133) \% \text {, measurement errors with respect to the unperturbed E-field } \\
\text { value. However, still the uncertainty of exposure assessments using a single } \\
\text { exposimeter remains significantly higher than the assessment of the } \\
\text { unperturbed E-field using spot measurements. }\end{array}$ \\
\hline 4 & $\begin{array}{l}\text { Karpowicz J. \& } \\
\text { Gryz K. }\end{array}$ & 2013 & $\begin{array}{l}\text { An assessment of hazards caused by } \\
\text { electromagnetic interaction on } \\
\text { humans present near short-wave } \\
\text { physiotherapeutic devices of } \\
\text { various types including hazards for } \\
\text { users of electronic active }\end{array}$ & $\begin{array}{l}\text { Leakage of electromagnetic fields (EMF) from short-wave radiofrequency } \\
\text { physiotherapeutic diathermies (SWDs) may cause health and safety hazards } \\
\text { affecting unintentionally exposed workers (W) or general public (GP) } \\
\text { members (assisting patient exposed during treatment or presenting there for } \\
\text { other reasons). Near capacitive applicators emitting continuous wave, the } \\
\text { corresponding distances were: } 120 \mathrm{~cm} \text { for } \mathrm{W} \text { or } 150 \mathrm{~cm} \text { for both-GP or }\end{array}$ \\
\hline
\end{tabular}




\begin{tabular}{|c|c|c|c|c|}
\hline $\mathbf{a} / \mathbf{a}$ & Authors & Year & Title & Methodology \& Results \\
\hline & & & $\begin{array}{l}\text { implantable medical devices } \\
(\text { AIMD). BioMed research } \\
\text { international, } 2013\end{array}$ & AIMD users. \\
\hline 5 & $\begin{array}{l}\text { Gryz K. \& } \\
\text { Krapowicz J.. }\end{array}$ & 2014 & $\begin{array}{l}\text { Environmental impact of the use of } \\
\text { radiofrequency electromagnetic } \\
\text { fields in physiotherapeutic } \\
\text { treatment. Roczniki Państwowego } \\
\text { Zakładu Higieny, } 65 \text { (1) }\end{array}$ & $\begin{array}{l}\text { The spatial distribution of electric and magnetic field strength was } \\
\text { investigated near } 3 \text { capacitive short-wave and } 3 \text { long-wave diathermies and } \\
3 \text { ultrasound therapy units, as along with the capacitive electric currents } \\
\text { caused by electromagnetic field interaction in the upper limbs of the } \\
\text { physiotherapists operating these devices. The strongest environmental } \\
\text { electromagnetic hazards occur near short-wave diathermy devices, and to a } \\
\text { lesser degree near long-wave diathermy devices, but were not found near } \\
\text { ultrasound therapy units }\end{array}$ \\
\hline 6 & $\begin{array}{l}\text { C. Koutsojannis } \\
\text { et al. }\end{array}$ & 2018 & $\begin{array}{l}\text { Microwave diathermy in } \\
\text { physiotherapy: Introduction and } \\
\text { evaluation of a quality control } \\
\text { procedure, Radiation Protection } \\
\text { Dosimetry (2018), Vol. 181, No. 3, } \\
\text { pp. 229-239 }\end{array}$ & $\begin{array}{l}\text { Microwave diathermies (MWDs) are electromagnetic (EM) radiation } \\
\text { emitting systems that are used by physiotherapists for thermotherapy } \\
\text { treatment. The results of a survey in Greece revealed serious concerns about } \\
\text { the safety of users and coexisting patients. The proposed approach could } \\
\text { result in the introduction of EM-screened rooms, ensuring that MWD users } \\
\text { and other persons in the vicinity will not be exposed to EM radiation over } \\
\text { reference levels. }\end{array}$ \\
\hline 7 & Stacy Eltiti et al. & 2007 & $\begin{array}{l}\text { Does Short-Term Exposure to } \\
\text { Mobile Phone Base Station Signals } \\
\text { Increase Symptoms in Individuals } \\
\text { Who Report Sensitivity to } \\
\text { Electromagnetic Fields? A Double- } \\
\text { Blind Randomized Provocation } \\
\text { Study, Environmental Health } \\
\text { Perspectives, Vol. } 115 \text {, No. } 11\end{array}$ & $\begin{array}{l}\text { Fifty-six self-reported sensitive and } 120 \text { control participants were tested in } \\
\text { an open provocation test. Of these, } 12 \text { sensitive and } 6 \text { controls withdrew } \\
\text { after the first session. The remainder completed a series of double-blind } \\
\text { tests. Subjective measures of well-being and symptoms as well as } \\
\text { physiological measures of blood volume pulse, heart rate, and skin } \\
\text { conductance were obtained. Short-term exposure to a typical GSM base } \\
\text { station-like signal did not affect well-being or physiological functions in } \\
\text { sensitive or control individuals. }\end{array}$ \\
\hline 8 & $\begin{array}{l}\text { Sabine J. Regel } \\
\text { et al. }\end{array}$ & 2006 & $\begin{array}{l}\text { UMTS Base Station-like Exposure, } \\
\text { Well-Being, and Cognitive } \\
\text { Performance, Environmental Health } \\
\text { Perspectives, } 114 \text { (8): 1270-1275 }\end{array}$ & $\begin{array}{l}\text { A total of } 117 \text { healthy subjects ( } 33 \text { self-reported sensitive, } 84 \text { non sensitive } \\
\text { subjects) participated in the study. There were assessed well-being, } \\
\text { perceived field strength, and cognitive performance with questionnaires and } \\
\text { cognitive tasks and conducted statistical analyses using linear mixed } \\
\text { models. Organ-specific and brain tissue-specific dosimetry. No conclusions } \\
\text { can be drawn regarding short-term effects of cell phone exposure or the } \\
\text { effects of long-term base station-like exposure on human health. }\end{array}$ \\
\hline 9 & P. C. Huang et al. & 2018 & $\begin{array}{l}\text { Association between media } \\
\text { coverage and prevalence of } \\
\text { idiopathic environmental } \\
\text { intolerance attributed to } \\
\text { electromagnetic field in Taiwan, } \\
\text { Environmental Research } 161 \text { (2018) } \\
329-335\end{array}$ & $\begin{array}{l}\text { From } 2007 \text { to 2012, the other potential affecting factors such as density of } \\
\text { mobile phone base stations, number of mobile phone users, total mobile } \\
\text { phone calling time, and number of text messages sent through mobile } \\
\text { phones all increased in Taiwan. This finding indicated a positive association } \\
\text { between media coverage and the prevalence of IEI-EMF in Taiwan, which } \\
\text { might also be true in other countries. }\end{array}$ \\
\hline 10 & $\begin{array}{l}\text { Aaron Reuben; } \\
\text { Avshalom Caspi, } \\
\text { Daniel W. } \\
\text { Belsky, et al. }\end{array}$ & 2017 & $\begin{array}{l}\text { Association of Childhood Blood } \\
\text { Lead Levels With Cognitive } \\
\text { Function and Socioeconomic Status } \\
\text { at Age } 38 \text { Years and With IQ } \\
\text { Change and Socioeconomic } \\
\text { Mobility Between Childhood and } \\
\text { Adulthood, Jama Psychiatric 2017; } \\
317 \text { (12): } 1244-1251\end{array}$ & $\begin{array}{l}\text { A prospective cohort study based on a population-representative 1972-1973 } \\
\text { birth cohort from New Zealand; the Dunedin Multidisciplinary Health and } \\
\text { Development Study observed participants to age } 38 \text { years (until December } \\
\text { 2012). A direct association between greater blood lead levels and a decline } \\
\text { in IQ and socioeconomic status from childhood to adulthood was observed } \\
\text { with } 40 \% \text { of the association with downward mobility mediated by cognitive } \\
\text { decline from childhood. Childhood lead exposure may have long-term } \\
\text { ramifications. }\end{array}$ \\
\hline
\end{tabular}

Thus based on the above studies, is necessary for the pollution monitoring the establishing and management an online intelligent environmental observation system for monitoring and evaluating public health hazard from human exposure to environmental (indoor and outdoor) pollutants.

According to the previous works for this pilot Environmental Observatory (EO) model, we chose the area of Western Achaea, in Western Greece region, as fulfills all the conditions in order to be a representative location for the EO simulation model. In this area are located urban centers, an industrial zone, cultural, religious and traditional "sea and sun" mass-tourism in an annual base. There is a large wastewater treatment plant, near Peiros river and CAST, while within the administrative boundaries is located the military and civilian airport. The geomorphological and hydrogeological bas-relief comprises: Peiros and Larisos river basin.

\section{Research Methodology}

\subsection{Aim of the Study}

For this pilot Environmental Observatory (EO) model, we chose the area of Western Achaea, in Western Greece region, as fulfills all the conditions in order to be a representative location for the EO simulation model. In this area are located urban centers, an industrial zone, cultural, religious and traditional "sea and sun" mass-tourism in an annual base. There is a big unit of a biological sewage treatment near Peiros river and CAST, while within the administrative 
boundaries is located the military and civilian airport. The geomorphological and hydrogeological bas-relief comprises: Peiros and Larisos river basins (with their estuary in Gulf of Patras and Ionion Sea), large agricultural plains, high-plains, mountain areas, intermittent and ephemeral streams. The coastal forest Strofylia along with Kotychi lagoon, are part of the Strofylia National Park (organized in 2009) also of great importance. The forest takes up about 5,500 acres and borders the Kotychi lagoon, the marsh of Lamia, the Prokopos lake and the Ionian Sea. The protected (Ramsar convention, Natura 2000, Life) ecosystem has concentrations of brackish and fresh water, while the forest, together with the nearby lagoon, make up an important and vibrant ecosystem, characterized as a refuge of wild life, a home to many species.

The objective of this study constitutes the search and recording, selected through the international literature, case studies, operation of environmental observation centers that monitoring and record the environmental pollutants in waters (lagoon, rivers, seaside), soil and air. In the end, through the extensive study of all good practices, the environmental observatories centers and also the reviews of how the effects of environmental pollution on the human health will end up to the best practice. With this optimum result the goal is to create and establish a modern intelligent environmental observatory (I. E. O.). If this model succeed in Western Greek Region then it could be applied to the whole Greek territory.

In the present work, there has been an in-depth and thorough survey in the international literature, for similar methodologies (related works) and also new techniques used in environmental observatories and research centers/institutions, worldwide, regarding to the detection, monitoring, management and reporting the environmental pollutants (with unknown toxic or radioactive action) in soil, vegetation, air, water and human body. This is accomplished with the development and implementation of all modern and traditional sampling methods, analyses and interpretation of parametric values, in combination with the use of high technology equipment. Below follows, a brief review of extant literature on the various methodologies and models according to the categories: air, soil, waters, human health, radiation as in details presented in Table 1-6.

\subsection{Model Development}

An implementation of laboratory testing of water samples, air samples, soil samples selected from various locations (natural resources/sources, natural recipients and areas of human installations or activities of high pollution hazard), at diverse times and on different days of week. Due account shall be given to pollutant measured values in various locations with a history (eg. Industrial zone, airport, limestone quarry) of the most dangerous toxic pollutants, in particular dioxins and furans (Ketones, ultrafine particles PM10, PM2.5, NOx, PAHs, $\mathrm{Na}, \mathrm{NO}^{-3}, \mathrm{SO}^{-2}, \mathrm{Cl}^{-}$and $\mathrm{NH}^{+}$, $\mathrm{O}_{3}$, SOx, VOCs) as well as heavy metals (eg Al, $\mathrm{Cu}, \mathrm{Zn}, \mathrm{Ag}$, $\mathrm{Cd}, \mathrm{As}, \mathrm{Hg}, \mathrm{BaP}, \mathrm{Cr}, \mathrm{Sb}, \mathrm{BaA}, \mathrm{BbF}$ ), as well as levels of non- ionizing or ionizing radiation.

Therefore an installation of small measurement stations using accurate continuous measurement systems shall significantly reduce personnel, equipment and financial resources requirements included in the laboratory context, is planned. With smart technology (drones) and wireless sensor platforms, equipped with multiple sensors able to measure the most relevant water quality parameters $[\mathrm{pH}$, dissolved oxygen-DO, oxidation-reduction potential-ORP, conductivity/salinity, turbidity, temperature and dissolved ions $\left(\mathrm{F}^{-}, \mathrm{Ca}^{+2}, \mathrm{NO}^{-3}, \mathrm{Cl}^{-}, \mathrm{I}^{-}, \mathrm{Cu}^{+2}, \mathrm{Br}^{-}, \mathrm{Ag}^{+}, \mathrm{BF}^{-4}, \mathrm{NH}_{4}, \mathrm{Li}^{+}\right.$, $\mathrm{Mg}^{+2}, \mathrm{NO}^{-2}, \mathrm{ClO}_{4}, \mathrm{~K}^{+}, \mathrm{Na}^{+}$), is feasible water monitoring for chemical leakage detection in rivers, lakes, streams, lagoon and levels of seawater pollution. industrial area and, with system of remotely notice, so that is located immediately each reject of sewages and are held immediately sampling and complete analysis. Important is the role of drones equipped with specific type of sensors and the ability of smart sampling or testing of environmental samples ranging from water, soil to air from sea, rivers, lagoon and atmosphere. The exported results will be expressed through certain indicators of pollution (hybrid pollution index) per category (soil, water, air) which will characterize the environmental quality of a given place (With the algorithm of source, the path, and receptor).

We decided that in this study we should design our methodology research using properly "mixed methods" thus according Cresswell (2003, p. 5) “...provides a better understanding of research problems than either approach alone". We conducted a thorough review of the existing literature on the subject and the worldwide environmental centers. Aim is the foundation and operation of a Smart Environmental Observation Centre model. The process of monitoring and sampling collection (automatically or manually) will provide us with the important and critical data for management (the information that they will be taken with conventional or technical way. By the analysis results of the toxicity indicators and the environmental hazards of pollutants, the climatic and meteorological data, in combination with the satellite photographs (image analysis) and the wireless monitoring via portable devices, gives useful conclusions on the current threat level of the environmental pollutants reported by individuals. Moreover the use of the artificial intelligence (AI) and simulators of human body (whole body phantom models) attempts a more accurate qualitative and quantitative (worst-best scenario) forecast. Thus we receive answers we are seeking about how many people are exposed to the environmental pollution and the severity of a medium/long-term situation. In this way with the exploitation of statistical analysis software, precious conclusions can be exported regarding to the future health of residents (possible event of illnesses, allergies, autoimmune diseases of in-depth time) according to the age, the sex, the social and professional order, their activities or their house location. Finally we can evaluate the areas where inhabitants live with poor medium or high well-being. 


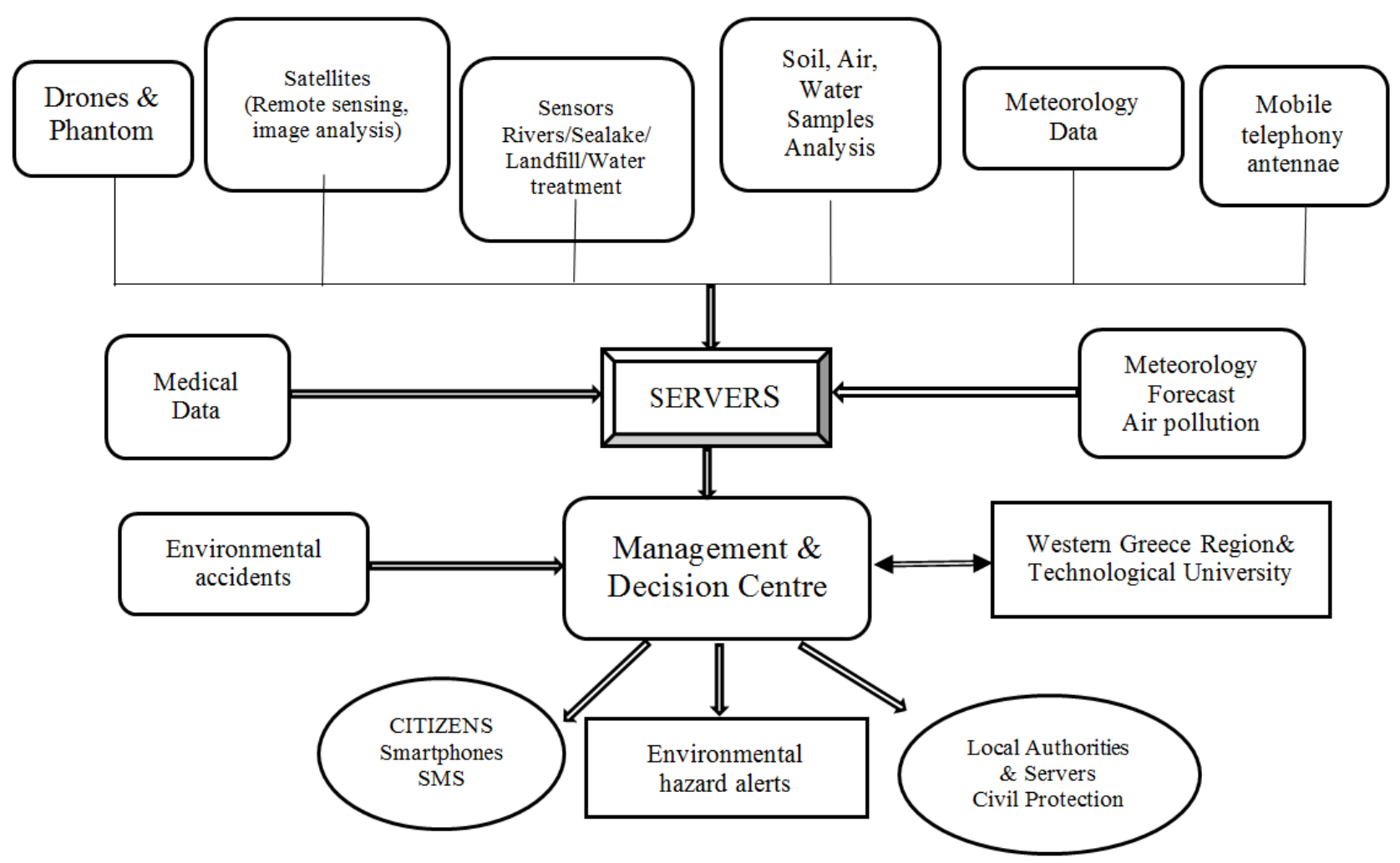

Figure 1. The proposed ENVIRONMENTAL OBSERVATION CENTRE model.

\subsection{Overview of the Pilot Study}

Environmental measurement includes data collection activity or investigation involving the assessment of chemical, physical, or biological factors in the environment which affect the environment, human health or the quality of life. Monitoring (including laboratory testing) and measuring (passive and active sampling) of waste (waste composition, landfill gases and leaks) noise, air, water, soil and sediments pollution, ionizing and not ionizing radiation, is necessary in order to assess the extent of the project's compliance with national regulations, quality standards and laws. According to the World Health Organization, prolonged exposure to pollution can lead to serious health effects. Long and short term exposure to toxicants has a different toxicological impact on human including the eyes irritation, skin diseases, etc. Most long-term chronic diseases such as cancer respiratory and cardiovascular diseases, neuropsychiatric complications Alzheimer disease, Parkinson disease. Pollutants mediated by the human endocrine system and by the brain, such as sleep disturbance, cardiovascular diseases, annoyance (a feeling of discomfort affecting general wellbeing), cognitive impairment and mental health problems will exist the estimate and forecast with regard to how many they medium- or long-term can immediately or indirectly, (in the near term, and in total) they overload and harm the health of persons. Will exist the possibility of equitable management of the smart platform model from the Region of Western Greece in close collaboration with Technological University of Western Greece and the Municipalities, from a strictly determined team of professors, scientists and executives of public administration. The results of measurements, in combination with the short and mediumterm "ecological forecast" for the potential spread of pollution (chemical gas plume, spreading of pollution in waters, etc), will constitute a tool for a rational strategic planning. The implementation of targeted actions for health promotion, concretization of environment protection policies and crises management will be of crucial importance. Furthermore, they will contribute considerably in the strategic planning and in the decision-making critical political, regarding the infrastructures, the investments and in general the development in all sectors (primary, secondary etc) and into research or technological human activities. With the systematic residents' health monitoring, are ensured its quality upgrade and their well-being. Finally, it can constitute a field of education of new scientists and executives of public institutions but also exchange of know-how with scientists from the Hellenic space and from all world. 


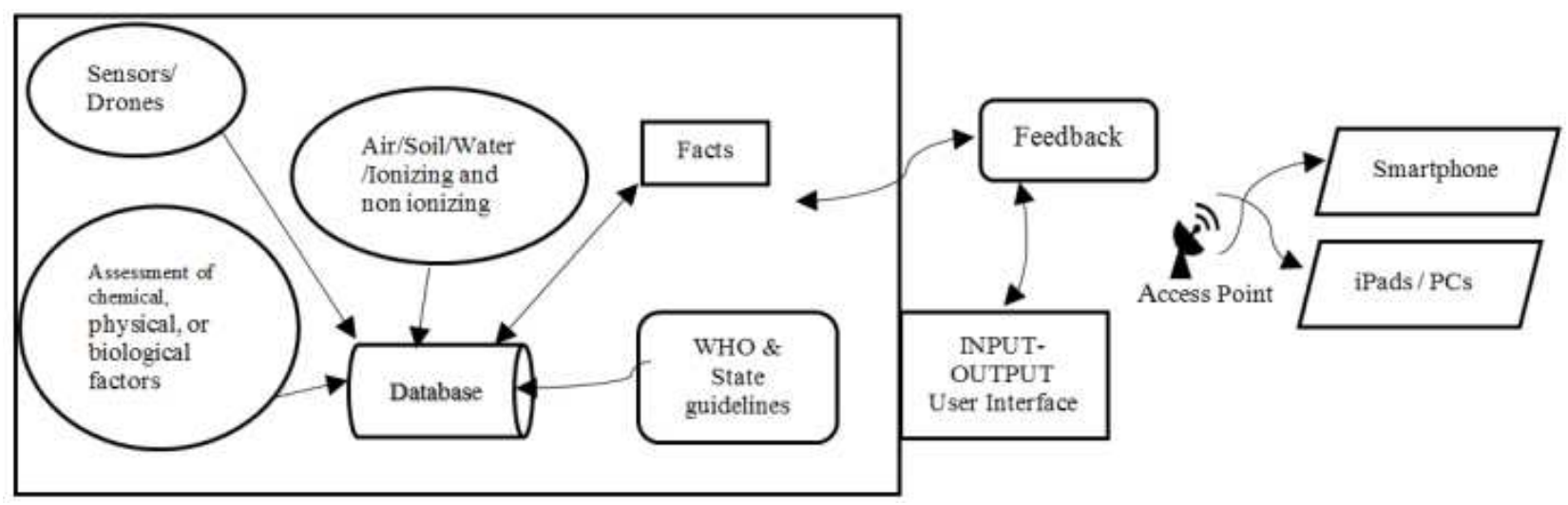

Figure 2. General Structure of intelligent management and decision centre.

\section{Results and Discussion}

Following the extended literature research that was presented above, this new model of Intelligent Environmental Monitoring and Management System (IEMMS) will be completely functional and it will give per passes moment (online) precise elements for the all environmental parameters (physicochemical, microbiological, electromagnetic and other radiation, dust, noise, satellite data, geography, geology) that they are transmitted wireless by their tens stations of measurement at the same type as presented in [6, 7] approaches. The collected data will be analyzed automatically as presented in [7] systems.

With the application of technology (Artificial Intelligence), we will succeed simulation of human body and its operations in the measured environmental values and impacts. A modern environmental observatory that will also function as environmental management and decision support model, with regard to the effects of pollution on human health.

The parameter values for various pollutants in each region and its natural and microbiological characteristics use of powerful software of statistical analysis and treatment of big data can link to useful conclusions on the tendency of pollution (per region) and the impact of these pollutants on human body.

Monitoring, recording and analysis of the dangerous and toxic for human health, physicochemical and microbiological pollutants, could constitute a medium-term or long-term tool for the ecological planning of young person house of model of growth of modern Municipality as presented in [60] and according to $[126,127]$ approaches. For example, this model (prototype) it would be feasible to propose a more rational "clean" primary, secondary and tertiary sector development, with the imaging in a kind of an "Environmental Pollution Chart" map. The purpose of such a map would be the aid in the prevention of health of residents with the evasion of report of these in charged with environmental pollutants regions as presented in $[117,118,122]$ models.

In the modern developed states, the "ecological forecast" could contribute considerably in the strategic planning and in the decision-making critical regarding infrastructures and investments in the rural sector, in the tourism, in the culture, in the trade even in the athletic installations and activities, contributing with the better way in the upgrade of inhabitants' quality or way of life, either they visit or they go through the different areas within the range of the Smart Environmental Observatory as presented in [32, 126] approaches.

Finally, under the proposed approach, data acquisition, processing and analysis of measured values for various kinds of pollutants from environmental overloaded surfaces, useful conclusions are drawn regarding to the "pollution tendency" in every different area and the possible effects on human in combination with geography and geomorphology. With the use of Big Data approach and AI technologies in human body simulators (whole body phantom models) combined with regional established death reports, we intend to make a more accurate qualitative and quantitative forecast: worst-best scenario, about as the life quality for residents -who may be exposed to the pollutants- as the direct or indirect medium to long-term adverse effects [28, 137].

\section{Conclusions}

Our inference is that the best way to accomplish a reliable and effective study is follow a combination of various methodologies of quantitative and qualitative research. We therefore conclude that, the most appropriate methods in our study are a mixture of qualitative, quantitative research, longitudinal and cross-sectional research and classification research $[1,5,8,11,13,21,23,29,32,33,42,48,52,53,76$, $79,91,92,95,98,106,113,124,126,129,136,140,142]$.

The precious conclusions drawn up by the course of residents' health (potential illnesses, allergies, autoimmune diseases over time) regarding to age, sex, social and professional class, activities and the place of residence as presented in [119] approach. In fact, it renders easier the environmental monitoring programs, the confrontation of problems and the diffusion of information. Furthermore, it becomes more effective and efficient for the citizens benefit along with officials, researchers, scientists, students, institutes ecc. Environmental footprints already include local or global supply chains when they show us the impacts of air, water, soil pollution or radiation. But what if in addition to showing you 
how many mgrs of contaminants, heavy metals or even pesticide exposure and adverse health effects at the clinical, hematological and biochemical level, pollution causes, the footprint came with maps/charts showing where that pollution is driving citizens' health? With pollutants footprints the prediction of increasing pollution, will provide us with critical informations and permit a better management, with the use of functional analysis tools such as GIS [21, 24, 28, 79].

\section{References}

[1] Blades, E., Naidu, R. P., \& Mathison, G. E. (1998). The microbiological analysis of Sahara dust and its association with asthma in Barbados. West Indian Med. J, 47 (suppl. 2), 34-5.

[2] Finkelman, R. B. (2019). The influence of clays on human health: A medical geology perspective. Clays and Clay Minerals, 67 (1), 1-6.

[3] Iturburu, F. G., Calderon, G., Amé, M. V., \& Menone, M. L. (2019). Ecological Risk Assessment (ERA) of pesticides from freshwater ecosystems in the Pampas region of Argentina: Legacy and current use chemicals contribution. Science of The Total Environment, 691, 476-482.

[4] Boone, J. S., Vigo, C., Boone, T., Byrne, C., Ferrario, J., Benson, R.,... \& Glassmeyer, S. T. (2019). Per-and polyfluoroalkyl substances in source and treated drinking waters of the United States. Science of the Total Environment, $653,359-369$.

[5] Eleftheria Chalvatzaki, Thodoros Glytsos \& Mihalis Lazaridis, A methodology for the determination of fugitive dust emissions from landfill sites, International Journal of Environmental Health Research, 2015, Vol. 25, No. 5, 551-569.

[6] Ashok Kumar, Naveen K. Bellam, Anupma Sud, Performance of an industrial source complex model: Predicting long-term concentrations in an urban area, Environmental Progress 2004, Vol. 18. Issue 2, pp. 93-100.

[7] Victoria Aleksandropoulou \& Mihalis Lazaridis, Development and application of a model (ExDoM) for calculating the respiratory tract dose and retention of particles under variable exposure conditions, Air Qual Atmos Health (2013) 6: 13-26.

[8] Simon D. Griffiths et al., A study of particulate emissions during 23 major industrial fires: Implications for human health, Environment International 2018, Vol. 112, pp. 310323.

[9] K. Gyan et al., African dust clouds are associated with increased paediatric asthma accident and emergency admissions on the Caribbean island of Trinidad, Int $\mathrm{J}$ Biometeorol (2005) 49: pp. 371-376.

[10] Chiang C, Lai C, Chou P, Li Y, and Tu, Y 1999 ASIA PACIFIC Conference on the Built Environment. The Study On The Comprehensive Indicators Of Indoor Environment Assessment For Occupants' Health. (Taipei, Taiwan) pp 1-7.

[11] W H W Ibrahim1, E Marinie, J Yunus, N Asra and K Mohd Sukor, Air quality assessment on human well-being in the vicinity of quarry site, IOP Conf. Series: Earth and Environmental Science 117 (2018) 012010.
[12] Athanasios Valavanidis Konstantinos Fiotakis and Thomais Vlachogianni, Airborne Particulate Matter and Human Health: Toxicological Assessment and Importance of Size and Composition of Particles, for Oxidative Damage and Carcinogenic Mechanisms, Journal of Environmental Science and Health Part C (2008), 26: pp. 339-362.

[13] E. Burte et al., Association between air pollution and rhinitis incidence in two European cohort, Environment International 115 (2018) 257-266.

[14] Mauro Masiol, Roy M. Harrison, Aircraft engine exhaust emissions and other airport-related contributions to ambient air pollution: A review, Atmospheric Environment 95 (2014) 409-455.

[15] G. Valotto et al., Characterization and preliminary risk assessment of road dust collected in Venice airport (Italy), Journal of Geochemical Exploration 190 (2018) pp. 142-153.

[16] Chu et al., Observing System-Terra Moderate Resolution Imaging Global monitoring of air pollution over land from the Earth Spectroradiometer (MODIS), J. Geophys. Res., Vol. 108 (D21), 4661 (2003).

[17] Oscar Alvear, Nicola Roberto Zema, Enrico Natalizio, and Carlos T. Calafate, Using UAV-Based Systems to Monitor Air Pollution in Areas with Poor Accessibility, Journal of Advanced Transportation Volume 2017, Article ID 8204353, 14 pages.

[18] N. S. Duzgoren-Aydin (2008), Health Effects of Atmospheric Particulates: A Medical Geology Perspective, Journal of Environmental Science and Health Part C, 26: 1-39, 2008.

[19] L. M. Filimonova, A. V. ParshinV. A. Bychinskii, Air pollution assessment in the area of aluminum production by snow geochemical survey, Russian Meteorology and Hydrology October 2015, Volume 40, Issue 10, pp 691-698.

[20] Zhenxv Lan, Fengyuan Zhang, Jia Wang, Min Chen, Design and Implementation of a Dynamic Simulation System for Air Pollutant Diffusion - A Case Study of the Fangshan District, Beijing, China, J. Geol Geosci Volume 2 (1): 2018.

[21] D. Briggs et al., Mapping urban air pollution using GIS: a regression-based approach, Journal International Journal of Geographical Information Science Volume 11, 1997 - Issue 7.

[22] H. Catherine W. Skinner, The earth, source of health and hazards: An introduction to medical geology. Annual Review of Earth and Planetary, Sciences 2007; 35: 177-213.

[23] X. Peng et al. (2016),_Influence of quarry mining dust on $P M_{25}$ in a city adjacent to a limestone quarry: Seasonal characteristics and source contributions, Science of the Total Environment 550 (2016) pp. 940-949.

[24] Inmaculada Menendez et al., (2017) Saharan dust and the impact on adult and elderly allergic patients: the effect of threshold values in the northern sector of Gran Canaria, Spain, International Journal of Environmental Health Research, 2017 VOL. 27, NO. 2, 144-160.

[25] Yong Zha, Jay Gao, Jianjun Jiang, Heng Lu \& Jiazhu Huang, Normalized difference haze index: a new spectral index for monitoring urban air pollution. International Journal of Remote Sensing, Vol. 33, No. 1, 10 January 2012, pp. 309-321.

[26] L. Risom et al., Oxidative stress-induced DNA damage by particulate air pollution, Mutation Research 592 (2005) pp. 119-137. 
[27] C. A. Pope III, R. T. Burnett, M. J. Thun, E. E. Calle, D. Krewski, K. Ito, G. D. Thurston, Lung cancer, cardiopulmonary mortality, and long-term exposure to fine particulate air pollution, JAMA 287 (2002) pp. 1132-1141.

[28] B. Brunekreef, S. T. Holgate, Air pollution and health, Lancet 360 (2002) pp. 1233-1242.

[29] T Bellander et al., Using geographic information systems to assess individual historical exposure to air pollution from traffic and house heating in Stockholm, Environmental Health Perspectives VOLUME 109 | NUMBER 6 | June 2001.

[30] S. L. Penn et al., Modeling variability in air pollution-related health damages from individual airport emissions, Environmental Research 156 (2017) pp. 791-800.

[31] Jerrett, M. et al. (2009), Long-term ozone exposure and mortality. New Engl. J. Med. 360 (11), 1085-1095.

[32] Colin Wong and Rachel Wyles, Mapping concentrations of airborne matter to quantify the fugitive emissions discharge rate from a landfill, Greenhouse Gas Measurement \& Management $2|2012| 50-60$.

[33] E. N. Papadakis et. Al., A pesticide monitoring survey in rivers and lakes of northern Greece and its human and ecotoxicological risk assessment, Ecotoxicology and Environmental Safety 116 (2015) 1-9.

[34] Tengku Ibrahim, F. Othman and N. Z. Mahmood, Assessment of water quality of Sembilang River receiving effluent from controlled municipal solid waste (MSW) landfill in Selangor, IOP Conf. Series: Materials Science and Engineering 210 (2017) 012019

[35] Ujianti, R. M. D., Anggoro, S., Bambang, A. N., \& Purwanti, F. (2018, May). Water quality of the Garang River, Semarang, Central Java, Indonesia based on the government regulation standard. In Journal of Physics: Conference Series (Vol. 1025, No. 1, p. 012037). IOP Publishing.

[36] A. Allahyar and M. R. Sabour M R (2014), Multi-response optimization of Fenton process for applicability assessment in landfill leachate treatment, Waste Management 34 2528-2536.

[37] Abunama, T., Othman, F., Alslaibi, T., \& Abualqumboz, M. (2017). Quantifying the Generated and Percolated Leachate through a Landfill's Lining System in Gaza Strip, Palestine. Polish Journal of Environmental Studies, 26 (6).

[38] D. L. Jones, K. L. Williamson and A. G. Owen (2006), Phytoremediation of landfill leachate, Waste Management 26 825-837.

[39] T. Eggen, M. Moeder and A. Arukwe (2010), Municipal landfill leachates: A significant source for new and emerging pollutants, Science of the Total Environment 408 5147-5157.

[40] A. Fernandes, M. J. Pacheco, L. Ciriaco and A. Lopes (2015), Review on the electrochemical processes for the treatment of sanitary landfill leachates: Present and future, Applied Catalysis B: Environmental 176-7 183-200.

[41] Muhammad Umar, H. Abdul Aziz and M. S. Yusoff (2010), Variability of parameters involved in leachate pollution index and determination of LPI from four landfills in Malaysia, International Journal of Chemical Engineering 1-6.

[42] N. Yusof, A. Haraguchi, M. A. Hassan, M. R. Othman, M. Wakisaka and Y. Shiraj (2009), Measuring organic carbon, nutrients and heavy metals in rivers receiving leachate from controlled and uncontrolled municipal solid waste (MSW) landfills, Waste Management 2666-2680.

[43] Jiang M, Zeng G, Zhang C, Ma X, Chen M, et al. (2013), Assessment of Heavy Metal Contamination in the Surrounding Soils and Surface Sediments in Xiawangang River, Qingshuitang District, PLoS ONE 8 (8): e71176.

[44] Pradip Kumar Maurya and D. S. Malik (2018), Bioaccumulation of heavy metals in tissues of selected fish species from Ganga river, India, and risk assessment for human health, Human and Ecological Risk Assessment.

[45] C. D. Kassotis et al., Characterization of Missouri surface waters near point sources of pollution reveals potential novel atmospheric route of exposure for bisphenol A and wastewater hormonal activity pattern, Science of the Total Environment 524-525 (2015) 384-393.

[46] Krishna Woli, Toshiyuki Nagumo Ryusuke Hatano, Magnitude of Nitrogen Pollution in Stream Water due to Intensive Livestock Farming Practices, Soil Science and Plant Nutrition 48 (6): 883-887.

[47] Stavroula Galanopoulou, Andreas Vgenopoulos, Nikolaos Conispoliatis, DDTs and other chlorinated organic pesticides and polychlorinated biphenyls pollution in the surface sediments of Keratsini harbour, Saronikos gulf, Greece, Marine Pollution Bulletin Volume 50, Issue 5, May 2005, Pages 520-525.

[48] I. K. Konstantinou et al., The status of pesticide pollution in surface waters (rivers and lakes) of Greece. Part I. Review on occurrence and levels, Environmental Pollution 141 (2006) $555 \mathrm{e} 570$.

[49] K. E. Murray et al. (2010), Prioritizing research for trace pollutants and emerging contaminants in the freshwater environment, Environmental Pollution 158 (2010) 3462e3471.

[50] M. J. Martı'nez Bueno et al., Pilot survey of chemical contaminants from industrial and human activities in river waters of Spain, Intern. J. Environ. Anal. Chem. Vol. 90, Nos. 3-6, 15 March-15 May 2010, 321-343.

[51] M. Gustavsson et al., Pesticide mixtures in the Swedish streams: Environmental risks, contributions of individual compounds and consequences of single-substance oriented risk mitigation, Science of the Total Environment 598 (2017) pp. 973-983.

[52] Jens Hartmann et al., A Brief Overview of the GLObal RIver Chemistry Database, GLORICH, Procedia Earth and Planetary Science 10 (2014) 23-27.

[53] Michael Hendryx, Jamison Conley, Evan Fedorko, Juhua Luo and Matthew Armistead (2012), Permitted water pollution discharges and population cancer and non-cancer mortality: toxicity weights and upstream discharge effects in US ruralurban areas, Hendryx et al. International Journal of Health Geographics 2012, 11: 9.

[54] C. Aydinalp, E. A. Fitz Patrick, and M. S. Cresser, Heavy Metal Pollution in Some Soil and Water Resources of Bursa Province, Turkey, Communications in Soil Science and Plant Analysis, 36: pp. 1691-1716, 2005.

[55] X. Gao et al., Hydrological controls on nitrogen (ammonium versus nitrate) fluxes from river to coast in a subtropical region: Observation and modeling, Journal of Environmental Management 213 (2018) 382e391. 
[56] Anna Jurado, Enric Vàzquez-Suñéa, Jesus Carrera, Miren López de Alda, Estanislao Pujades, Damià Barceló, Emerging organic contaminants in groundwater in Spain: A review of sources, recent occurrence and fate in a European context, Science of The Total Environment Volume 440, 1 December 2012, Pages 82-94.

[57] Biplob Das, Rick Nordin, Asit Mazumder, Watershed land use as a determinant of metal concentrations in freshwater systems, Environmental Geochemistry and Health December 2009, Volume 31, Issue 6, pp 595-607.

[58] A. Schaeffer, H. Hollert, H. T. Ratte, M. Ross-Nickoll, J. Filser, M. Matthies, J. Oehlmann, M. Scheringer, R. Schulz, A. Seitz, An indispensable asset at risk: merits and needs of chemicals-related environmental sciences, Environ. Sci. Pollut. Res. 16 (2009) 410-413.

[59] R. Meffe, I. de Bustamante, Emerging contaminants in surface water and groundwater: a first overview of the situation in Italy, Sci. Total Environ. 481 (2014) 280-295.

[60] B. Petrie, R. Barden, B. Kasprzyk-Hordern, A review on emerging contaminants in wastewaters and the environment: current knowledge, understudied areas and recommendations for future monitoring, Water Res. 71 (2015) 3-27.

[61] M. Stuart, D. Lapworth, E. Crane, A. Hart, Review of risk from potential emerging contaminants in UK groundwater, Sci. Total Environ. 416 (2012) 1-21.

[62] R. W. Masters, I. M. Verstraeten, T. Heberer, Fate and transport of pharmaceuticals and endocrine disrupting compounds during ground water recharge, Ground Water Monit. Remediat. 24 (2004) 54-57.

[63] L. Lamastra et al., Inclusion of emerging organic contaminants in groundwater monitoring plans, Methods X 3 (2016) pp. 459-476.

[64] X. Y. Miao, J. J. Yang, C. D. Metcalfe, Carbamazepine and its metabolites in wastewater and in biosolids in a municipal wastewater treatment plant, Environ. Sci. Technol. 39 (19) (2005) 7469-7475.

[65] M. Zafar and B. J. Alappat, Landfill Surface Runoff and Its Effect on Water Quality on River Yamuna, JOURNAL OF ENVIRONMENTAL SCIENCE AND HEALTH Part AToxic/Hazardous Substances \& Environmental Engineering Vol. A39, No. 2, pp. 375-384, 2004.

[66] Fakayode, S. O. (2005), Impact assessment of industrial effluent on water quality of the receiving Alaro river in Ibadan Nigeria, AJEAM-RAGEE 10: 1-13.

[67] Kanu, Ijeoma and Achi, O. K. (2011), Industrial Effluents and Their Impact on Water Quality of Receiving Rivers in Nigeria, Journal of Applied Technology in Environmental Sanitation, 1 (1): 75-86.

[68] Lucrezia Lamastra, Matteo Balderacchi, Marco Trevisan, Inclusion of emerging organic contaminants in groundwater monitoring plans, MethodsX Volume 3, 2016, Pages 459-476.

[69] Nubi, O. A. 1 Osibanjo, O. Nubi, A. T. 2008 Impact assessment of dumpsite leachate on the qualities of surface water and sediment of river Eku, Ona-Ara local government, Oyo State, Nigeria. Science World Journal 3 (3): 17-20.
[70] Udiba U. U., Gauje Balli, Ashade N. O., Ade-Ajayi F. A., Okezie V. C., Aji B. M. and Agboun T. D. T., An assessment of the heavy metal status of River Galma around Dakace industrial layout, Zaria, Nigeria, Merit Research Journal of Environmental Science and Toxicology (ISSN: 2350-2266) Vol. 2 (8) pp. 176-184, November, 2014.

[71] Udiba U. U., Anyanwu Stella, Gauje Balli, Dawaki S. I., Oddy-Obi I. C., Agboun T. D. T. Toxicity Potential of Allium cepa L. as a Bioindicator of Heavy Metal Pollution Status of River Galma Basin Around Dakace Industrial Layout, Zaria, Nigeria, International Journal of Biological Sciences and Applications 2015; 2 (6): 76-85.

[72] D. Yu et al., Modeling increased riverine nitrogen export: Source tracking and integrated watershed-coast management, Marine Pollution Bulletin 101 (2015) 642-652.

[73] F. Riva et al., Monitoring emerging contaminants in the drinking water of Milan and assessment of the human risk, International Journal of Hygiene and Environmental Health 221 (2018) 451-457.

[74] S. T. Glassmeyer et al., Nationwide reconnaissance of contaminants of emerging concern in source and treated drinking waters of the United States, Science of the Total Environment 581-582 (2017) pp. 909-922.

[75] Christina I. Nannou, Christina I. Kosma and Triantafyllos A. Albanis, Occurrence of pharmaceuticals in surface waters: analytical method development and environmental risk assessment, International Journal of Environmental Analytical Chemistry, 14th Symposium on Chemistry and Fate of Modern Pesticides, Ioannina, Greece (18-21 September 2014).

[76] J. Robles-Molina, F. J. Lara-Ortega, B. Gilbert-López, J. F. García-Reyes and A. Molina-Díaz, J. Chromatogr, Multiresidue method for the determination of over 400 priority and emerging pollutants in water and wastewater by solid-phase extraction and liquid chromatography-time-of-flight mass spectrometry, Journal of Chromatography A Volume 1350, 11 July 2014, Pages 30-43 A 1350, 30 (2014).

[77] Cupit M, Larsson O, de Meeûs C, Eduljee GH, Hutton MC., Assessment and management of risks arising from exposure to cadmium in fertilisers - I, / The Science of the Total Environment 291 (2002) 167-187.

[78] Zhongmin Jia1, Siyue Li \& Li Wang, Assessment of soil heavy metals for eco-environment and human health in a rapidly urbanization area of the upper Yangtze Basin, SCIEnTIfIC Reports | (2018) 8: 3256 DOI: 10.1038/s41598-018-21569-6.

[79] Olivier Núñez et al., Association between heavy metal and metalloid levels in topsoil and cancer mortality in Spain, Environ Sci Pollut Res (2017) 24: 7413-7421.

[80] Rosemary et al., Concentrations of Trace Metals in Selected Land Uses of a Dry Zone Soil Catena of Sri Lanka, Tropical Agricultural Research Vol. 25 (4): 512-522 (2014).

[81] Nisreen Tamimi, Dörte Diehl, Mohand Njoum, Amer Marei, Gabriele E. Schaumann, Effects of olive mill wastewater disposal on soil: Interaction mechanisms during different seasons, J. Hydrol. Hydromech., 64, 2016, 2, 176-195.

[82] L. R. Lado et al., Heavy metals in European soils: A geostatistical analysis of the FOREGS Geochemical database, Geoderma 148 (2008) 189-199. 
[83] G. Tóth et al., Heavy metals in agricultural soils of the European Union with implications for food safety, Environment International 88 (2016) 299-309.

[84] P. Saikkonen, Knowledge Production and Polluted Soil in Urban Planning: The Case of Helsinki, Journal of Environmental Policy \& Planning, 2015 Vol. 17, No. 5, 538-552.

[85] Alamdar et al. Organochlorine pesticides in surface soils from obsolete pesticide dumping ground in Hyderabad City, Pakistan: Contamination levels and their potential for air-soil exchange, Science of the Total Environment 470-471 (2014) 733-741.

[86] G. Shi et al. Potentially toxic metal contamination of urban soils and roadside dust in Shanghai, China, Environmental Pollution 156 (2008) 251-260.

[87] Viacheslav Vasenev, Yakov Kuzyakov, Urban soils as hot spots of anthropogenic carbon accumulation: Review of stocks, mechanisms and driving factors, Land Degrad Dev. 2018; 29: 1607-1622.

[88] Peter W. Abrahams, Soil, geography and human disease: a critical review of the importance of medical cartography, Progress in Physical Geography 30, 4 (2006) pp. 490-512.

[89] E. C. Brevik and T. J. Sauer, The past, present, and future of soils and human health studies, SOIL, 1, 35-46, 2015, www.soil-journal.net/1/35/2015/.

[90] A. Moretto, C. Colosio, The role of pesticide exposure in the genesis of Parkinson's disease: Epidemiological studies and experimental data, Toxicology 307 (2013) 24-34.

[91] A. Gebrekidan et al., Toxicological assessment of heavy metals accumulated in vegetables and fruits grown in Ginfel river near Sheba Tannery, Tigray, Northern Ethiopia, Ecotoxicology and Environmental Safety 95 (2013) 171-178.

[92] M. T. Baltazar et al., Pesticides exposure as etiological factors of Parkinson's disease and other neurodegenerative diseases-A mechanistic approach, Toxicology Letters 230 (2014) 85-103.

[93] Sharon K. Sagiv et al., Prenatal Organophosphate Pesticide Exposure and Traits Related to Autism Spectrum Disorders in a Population Living in Proximity to Agriculture, Environmental Health Perspectives 047012, 2018.

[94] A. Dabass et al., Systemic inflammatory markers associated with cardiovascular disease and acute and chronic exposure to fine particulate matter air pollution (PM2.5) among US NHANES adults with metabolic syndrome, Environmental Research 161 (2018) 485-491.

[95] C. R. García-García et al., Occupational pesticide exposure and adverse health effects at the clinical, hematological and biochemical level, Life Sciences 145 (2016) 274-283.

[96] L. S. Engel et al., Insecticide Use and Breast Cancer Risk among Farmers' Wives in the Agricultural Health Study, Environ Health Perspect. 2017 Sep; 125 (9): 097002.

[97] Louis et al., A prospective study of cancer risk among Agricultural Health Study farm spouses associated with personal use of organochlorine insecticides, Environmental Health (2017) 16: 95.

[98] Ming Ye1, Jeremy Beach, Jonathan W. Martin, Ambikaipakan Senthilselvan X, Pesticide exposures and respiratory health in general populations, Journal of Environmental Sciences 51 (2017) 361-370.
[99] C. Piccoli et al., Pesticide exposure and thyroid function in an agricultural population in Brazil, Environmental Research 151 (2016) 389-398.

[100] J. F. Lebov et al., Pesticide exposure and end-stage renal disease risk among wives of pesticide applicators in the Agricultural Health Study, Environmental Research 143 (2015) 198-210.

[101]A. Gómez-Martín et al., Polymorphisms of pesticidemetabolizing genes in children living in intensive farming communities, Chemosphere 139 (2015) 534-540.

[102] X Rupali Das, Andrea Steege, Sherry Baron, John Beckman \& Robert Harrison, (2001) Pesticide-related Illness among Migrant Farm Workers in the United States, Journal of Occupational and Environmental Health, 7: 4, 303-312.

[103] S. Mostafalou, M. Abdollahi, Pesticides and human chronic diseases: Evidences, mechanisms, and perspectives, Toxicology and Applied Pharmacology 268 (2013) 157-177.

[104] A. C. Edwards et al., Farmyards, an overlooked source for highly contaminated runoff, Journal of Environmental Management 87 (2008) 551-559.

[105] Senkayi et al., Investigation of an association between childhood leukemia incidences and airports in Texas, Atmospheric Pollution Research (APR) 5 (2014), 189-195.

[106] C. L. Callahan et al., Lifetime exposure to ambient air pollution and methylation of tumor suppressor genes in breast tumors, Environmental Research 161 (2018) 418-424.

[107] S. Singh et al., Influence of CYP2C9, GSTM1, GSTT1 and NAT2 genetic polymorphisms on DNA damage in workers occupationally exposed to organophosphate pesticides, Mutation Research 741 (2012) 101-108.

[108] W. Hu et al., Heavy metals in intensive greenhouse vegetable production systems along Yellow Sea of China: Levels, transfer and health risk, Chemosphere 167 (2017) 82e90.

[109]G. Ding et al., Increased levels of 8-hydroxy-20deoxyguanosine are attributable to organophosphate pesticide exposure among young children, Environmental Pollution 167 (2012) $110 \mathrm{e} 114$.

[110] A. Saad-Hussein et al., GSTP1 and XRCC1 polymorphisms and DNA damage in agricultural workers exposed to pesticides, Mutat Res Gen Tox En 819 (2017) 20-25.

[111] M. S. El-Shahawi et al., An overview on the accumulation, distribution, transformations, toxicity and analytical methods for the monitoring of persistent organic pollutants, Talanta 80 (2010) 1587-1597.

[112] Ramasamy Rajamanickam, S. Nagan, Assessment of Comprehensive Environmental Pollution Index of Kurichi Industrial Cluster, Coimbatore District, Tamil Nadu, India - a Case Study, Journal of Ecological Engineering Volume 19, Issue 1, January 2018, pages 191-199.

[113] J. S. Horsburgh et al., Components of an environmental observatory information system, Computers \& Geosciences 37 (2011) 207-218.

[114] Keller et al., A Unified Spatiotemporal Modeling Approach for Predicting Concentrations of Multiple Air Pollutants in the MultiEthnic Study of Atherosclerosis and Air Pollution, Environmental Health Perspectives volume 123 | number 4 | April 2015. 
[115] Kumar et al., The rise of low-cost sensing for managing air pollution in cities, Environment International 75, 2015, 199-205.

[116] G. Hoek et al., A review of land-use regression models to assess spatial variation of outdoor air pollution, Atmospheric Environment 42 (2008) 7561-7578.

[117] Ozgur Kisi, Kulwinder Singh Parmar, Application of least square support vector machine and multivariate adaptive regression spline models in long term prediction of river water pollution, Journal of Hydrology Volume 534, March 2016, Pages 104-112.

[118] G. Prud'homme et al., Comparison of remote sensing and fixed-site monitoring approaches for examining air pollution and health in a national study population, Atmospheric Environment 80 (2013) 161e171.

[119] Tamás Fráter et al., Unmanned Aerial Vehicles in Environmental Monitoring-An Efficient Way for Remote Sensing, Journal of Environmental Science and Engineering A 4 (2015) 85-91.

[120] Ozgur Kisi, Kulwinder Singh Parmar, Kirti Soni, Vahdettin Demir, Modeling of air pollutants using least square support vector regression, multivariate adaptive regression spline, and M5 model tree models, Air Quality, Atmosphere \& Health September 2017, Volume 10, Issue 7, pp 873-883.

[121] Arshia Chander et al., A new eye in the sky: Eco-drones, Environmental Development Volume 7, July 2013, Pages 155164.

[122] G. Di Stefano et al., The Lusi drone: A multi-disciplinary tool to access extreme environments Marine and Petroleum Geology 90 (2018) 26e37.

[123] José I. Suárez et al., Bluetooth Electronic Nose for Odour Monitoring and Control, Chemical Engineering transactions, Vol. 68, 2018.

[124] N. Castell et al., Can commercial low-cost sensor platforms contribute to air quality monitoring and exposure estimates?, Environment International 99 (2017) 293-302.

[125] A. Moreno-Rangel et al., Field evaluation of a low-cost indoor air quality monitor to quantify exposure to pollutants in residential environments, Journal of Sensors Sensor Systems, 7, 373-388, 2018.

[126] World Meteorological Organization (WMO), 2018, Low-cost sensors for the measurement of atmospheric composition: overview of topic and future applications, World Meteorological Organization (WMO).

[127] Stanislaw Anweiler, Dawid Piwowarski, Multicopter platform prototype for environmental monitoring, Journal of Cleaner Production Volume 155, Part 1, 1 July 2017, Pages 204-211.

[128] Schwela, Dieter. 2012. Review of urban air quality in SubSaharan Africa region - air quality profile of SSA countries (English). Washington, DC: World Bank.

[129] Prashant Kumar et al., The rise of low-cost sensing for managing air pollution in cities, Environ. Int. 2015 Feb; 75, 199-205.

[130] K. S. Adu-Manu et al., Water Quality Monitoring Using Wireless
Sensor Networks: Current Trends and Future Research Directions, Trans. Sensor Netw. 00, 00, Article 000 (2016).

[131] M. Pule et al., Wireless sensor networks: A survey on monitoring water quality, Journal of Applied Research and Technology 15 (2017) 562-570.

[132] Christopher J. Paciorek and Yang Liu, Assessment and Statistical Modeling of the Relationship Between Remotely Sensed Aerosol Optical Depth and PM 2.5 in the Eastern United States, 2012 HEI Research Report 167.

[133] I Maccà et al. (2008), Occupational exposure to electromagnetic fields in physiotherapy departments. Radiation protection dosimetry, 128 (2), 180-190.

[134] Gryz K. Zradziński, P. \& Karpowicz J, (2015), The role of the location of personal exposimeters on the human body in their use for assessing exposure to the electromagnetic field in the radiofrequency range $98-2450 \mathrm{MHz}$ and compliance analysis: evaluation by virtual measurements. BioMed research international, 2015.

[135] Shah S. G. S., \& Farrow A. (2014), Systematic literature review of adverse reproductive outcomes associated with physiotherapists' occupational exposures to non-ionising radiation. Journal of occupational health, 56 (5), 323-331.

[136] Karpowicz J. \& Gryz K. (2013), An assessment of hazards caused by electromagnetic interaction on humans present near short-wave physiotherapeutic devices of various types including hazards for users of electronic active implantable medical devices (AIMD). BioMed research international, 2013.

[137] Gryz K. \& Krapowicz J. (2014), Environmental impact of the use of radiofrequency electromagnetic fields in physiotherapeutic treatment. Roczniki Państwowego Zakładu Higieny, 65 (1).

[138] C. Koutsojannis et al, Microwave diathermy in physiotherapy: Introduction and evaluation of a quality control procedure, Radiation Protection Dosimetry (2018), Vol. 181, No. 3, pp. 229-239.

[139] Stacy Eltiti et al. (2007), Does Short-Term Exposure to Mobile Phone Base Station Signals Increase Symptoms in Individuals Who Report Sensitivity to Electromagnetic Fields? A DoubleBlind Randomized Provocation Study, Environmental Health Perspectives, Vol. 115, No. 11.

[140] Sabine J. Regel et al. (2006), UMTS Base Station-like Exposure, Well-Being, and Cognitive Performance, Environmental Health Perspectives, 114 (8): 1270-1275.

[141] P. C. Huang et al., Association between media coverage and prevalence of idiopathic environmental intolerance attributed to electromagnetic field in Taiwan, Environmental Research 161 (2018) 329-335.

[142] Aaron Reuben; Avshalom Caspi, Daniel W. Belsky, et al (2017), Association of Childhood Blood Lead Levels With Cognitive Function and Socioeconomic Status at Age 38 Years and With IQ Change and Socioeconomic Mobility Between Childhood and Adulthood, Jama Psychiatric 2017; 317 (12): 1244-1251. 